Article

\title{
Revisiting the Determinants of Pro-Environmental Behaviour to Inform Land Management Policy: A Meta-Analytic Structural Equation Model Application
}

\author{
Murat Okumah ${ }^{1, *}{ }^{\circ}$, Julia Martin-Ortega ${ }^{1}$, Paula Novo ${ }^{2}$ and Pippa J. Chapman ${ }^{3}$ \\ 1 Sustainability Research Institute, School of Earth and Environment, University of Leeds, Leeds LS2 9JT, UK; \\ J.MartinOrtega@leeds.ac.uk \\ 2 Rural Economy, Environment and Society Department, Scotland's Rural College (SRUC), \\ Edinburgh EH9 3JG, UK; paula.novo@sruc.ac.uk \\ 3 School of Geography, University of Leeds, Leeds LS2 9JT, UK; P.J.Chapman@leeds.ac.uk \\ * Correspondence: ee15sa@leeds.ac.uk
}

Received: 27 March 2020; Accepted: 27 April 2020; Published: 30 April 2020

\begin{abstract}
Environmental policies in the realm of land management are increasingly focussing on inducing behavioural change to improve environmental management outcomes. This is based, implicitly or explicitly, on theories that suggest that pro-environmental behaviour can be understood, predicted and altered based on certain factors (referred to as determinants of pro-environmental behaviour). However, studies examining the determinants of pro-environmental behaviour have found mixed evidence. It is therefore important that we revisit these theories to assess if the evidence supports their postulations so that a more robust knowledge base can be established to inform land management policies. In this study, we do this using meta-analytic structural equation modelling (MASEM) to explore whether the evidence on determinants of pro-environmental behaviour supports the postulations of some predominantly applied theories of behaviour and/or behaviour change. The study analyses research in four environmental policy areas to identify implications for land management. Evidence from these related environmental areas is expected to provide insights relevant to the land management literature and to allow us to identify the extent to which lessons on pro-environmental behaviour from these other areas can be transferred to the land management context. Our findings suggest a strong evidence base for the Theories of Planned Behaviour and Reasoned Action, Attitude-Behaviour-Context Model, and the Persuasion Theory, but a weak evidence base for the Value-Belief-Norm Theory and the Norm Activation Model. We also found that type of environmental policy area moderates the relationship between different variables. This has key policy implications since, while lessons can be learnt from other environmental policy areas, land management policies aimed at influencing behaviours will need to be tailored to the specific context rather than simply 'imported' from other fields. Such context-specific policies may encourage pro-environmental behaviours, and potentially contribute towards improving environmental management outcomes.
\end{abstract}

Keywords: best management practice; environmentally responsible behaviour; environmental awareness; environmental attitude; environmental knowledge; environmental policy

\section{Introduction}

Policies across the environmental sector are increasingly focussing on behavioural change as a means to improve environmental performance [1,2]. Behaviour focussed approaches are particularly prominent in the realm of land management, where policies are increasingly aimed at influencing 
land managers to take up best management practices to improve water quality, soil and human health and prevent further biodiversity loss [3-7]. Examples of these policies include the National Landcare Programme established in Australia in 1988 [8], the Water Quality Scheme and the Environmental Quality Incentive Programme in the United States of America in 1997, the Monitor Farms Programme established in 1991 in New Zealand [9], the Catchment Sensitive Farming Delivery Initiative started in 2005 in England [10,11] and the Diffuse Pollution Management Strategy established in 2009 in Scotland [12]. These policies acknowledge the role of a wide range of factors in understanding and influencing land managers' behaviours $[4,9,13-15]$. For instance, they place emphasis on land managers' awareness and attitudes under the expectation that this may encourage pro-environmental practices [16].

Despite the increasing popularisation of such policies, studies examining the determinants of pro-environmental behaviour in land management have found mixed evidence on their impact (e.g., [17-19]). Arguments have been made regarding the limitations of the behavioural theories that (implicitly or explicitly) underpin these policies. For instance, the assumption that awareness of best management practices results in pro-environmental behaviour has been criticised for being deterministic, as this may not apply in every situation $[9,16,20]$.

While these concerns are relevant and could help provide answers that may trigger new policy directions [21], there have been very few studies establishing whether existing evidence supports the postulations of the behavioural theories underpinning land management policies (i.e., policies guiding land use and management). One known study that attempts to establish this is the work of Bamberg and Moser [22]. However, while their study draws evidence from papers that rely on the Theory of Planned Behaviour and the Norm Activation Model, they do not test whether these theories were supported by the evidence or not; they tested a proposed integrative model of pro-environmental behaviour. While such an integrative approach provides a comprehensive understanding of the determinants of pro-environmental behaviour and behavioural change, it does not provide evidence specific to the theories. Additionally, although they acknowledged the potential influence of moderating factors, their study did not explore such factors. This study aims to establish whether the existing empirical evidence supports the predictions of (five) key theories of pro-environmental behaviour, with the particular purpose to improve the information base for land management policy. To do this, we use meta-analytic structural equation modelling (MASEM). The study analyses research in four environmental policy areas to identify implications for land management. Evidence from these related environmental areas is expected to provide insights relevant to the land management literature and to allow us to identify the extent to which lessons on pro-environmental behaviour from these other areas can be transferred to the land management context. We use the term "land management policies" to refer to policies that guide land related activities such as farming, forestry and woodland management. "Environmental management policies" on the other hand refer to policies that regulate all activities (such as recycling and farming) that could impact any aspects of the environment.

This work advances the literature in various ways. Firstly, unlike earlier meta-analytic reviews in the land management field that look only at the individual contributions of awareness, attitudes and situational factors (e.g., [16], this study covers the joint contributions of a larger range of variables (e.g., subjective norms, ascription of responsibility). MASEM allows us to test the mechanisms through which these different variables affect each other (i.e., it considers their mediated relationships) via correlations and multiple regressions [23]. Moreover, the evidence base that we explore goes beyond that of land management only, including other environmental sectors (e.g., recycling) as well as general ecological behaviours more broadly.

\section{Theoretical Basis}

In this section, we provide an overview of the five main behaviour theories: Persuasion Theory [24,25], Theories of Reasoned Action and Planned Behaviour [26,27], The Norm-Activation Model [28,29], the Value-Belief Norm Theory [30-33] and the Attitude-Behaviour-Context (ABC) 
Model [32] $]^{1}$. These theoretical frameworks cite environmental, personal and behavioural characteristics as the major factors in behaviour determination and are frequently applied by researchers trying to understand and explain pro-environmental behaviour [15,23,36,37]. In Figure 1, we present a theoretical framework that joins the various paths (e.g., knowledge-awareness link, awareness-behaviour link, knowledge-behaviour link) postulated in these theories. We use letters to represent the different pathways (e.g., knowledge-awareness link, awareness-behaviour link, knowledge-behaviour link) hypothesised in each of the theories. Therefore, the link between variables also show which determinants are related to the different theories.

\subsection{Persuasion Theory}

Persuasion Theory is one of the simplest models of behaviour, built on the idea of linear progression. Proponents of this model reasoned that behaviour change is realised through the provision of required information to the targeted actors [24]. It is argued that effective persuasion is contingent on three key elements, namely: the credibility or trustworthiness of the speaker (the source), power of the argument (the message) and the receptiveness of the audience (the recipient) [24]. In the context of environmental problems, the model assumes that the actors' current behaviour is due to some lack of awareness/knowledge regarding the right strategies to mitigate environmental problems; consequently, this model has more recently been termed the 'information deficit model' [38]. It is also assumed that attitude and behavioural change can only happen when individuals access the required information and assimilate it. Based on these assumptions, the model prescribes information provision as the solution, contending that information provision results in awareness, which in turn leads to a change in attitude and behaviour.

The model has been criticised for being deterministic as it assumes that information provision is a guarantee for realising the desired behaviour [21,38]. This deterministic view (if one becomes aware, one behaves desirably), overlooks the role of other multiple intervening factors (e.g., economic, cultural, social pressure) that determine outcomes of interventions, amidst information provision [21,38-40]. Behaviour and behaviour change are complex, therefore a strategy based only on 'information provision' will struggle to induce behavioural change. The linear perspective of the model is also problematic. Though the information-attitude-behaviour pathway appears reasonable, individuals can learn without necessarily assimilating the 'persuasive message', and behavioural change can occur without attitudinal influences [25].

Despite its flaws, the model has made contributions in influencing pro-environmental behaviours since its key elements are still relevant in behaviour, particularly for land manager behaviour. For example, research shows that for farmers, the source of information (e.g., the farm advisor) and the persuasiveness of the message are indeed crucial (albeit not necessarily sufficient) in determining whether the farmer acts upon the advice, particularly where the message is consistent, well-placed and positive [6,41]. Using MASEM, Bamberg and Moser [22] showed that awareness affects attitudes towards pro-environmental behaviours, and this in turn affect behaviours (through intentions to act).

1 The Social learning theory has also been applied to understand individual and group pro-environmental behaviours related to networking and the development of tacit knowledge [34] [This theory regards behavioural change as a learning process where the individual moulds his/her behaviour by observing and learning from their environment mainly through interactions and personal communication [35]. This theory was not tested in the present study due to a lack of data for variables that explicitly measure experiential learning and how knowledge is acquired through networking. 


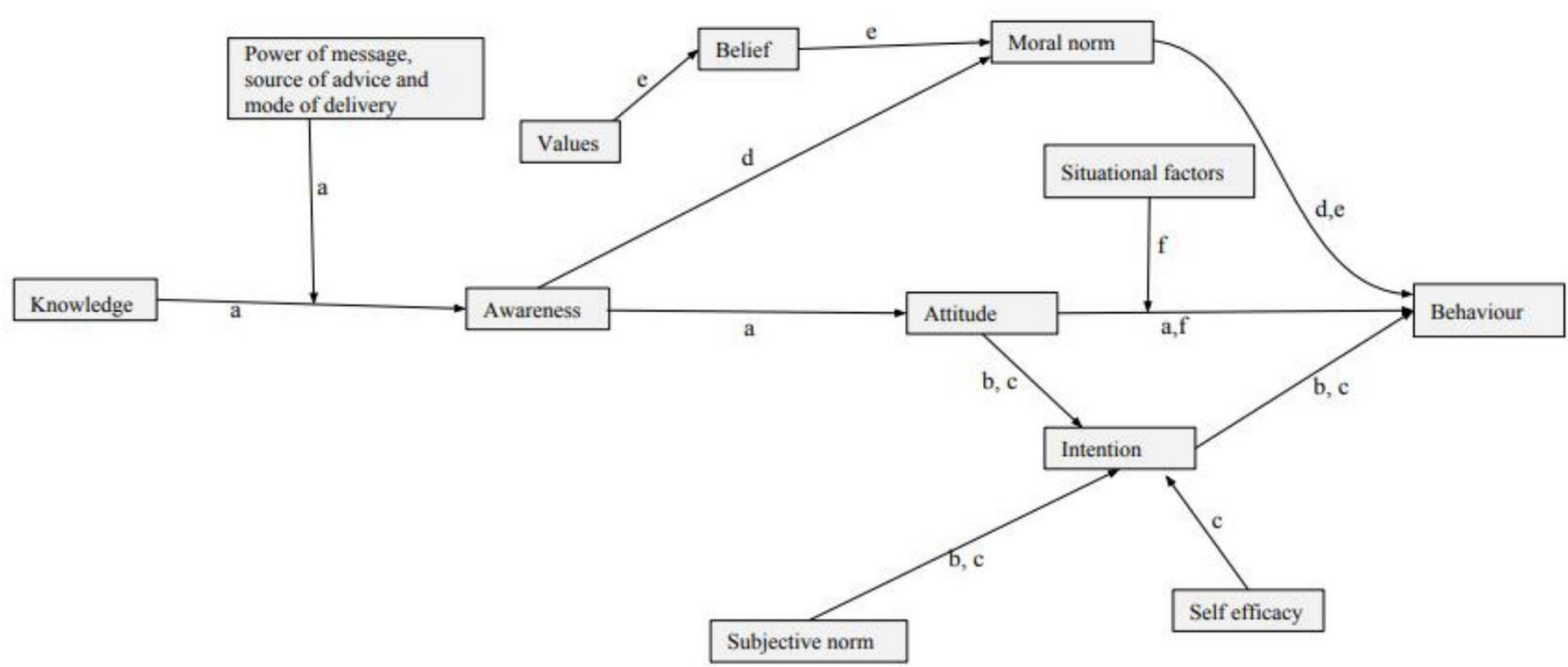

Key

Persuasion theory $=\mathrm{a}$

Theory of Planned Behaviour $=b$

Theory of reasoned action $=\mathrm{c}$

\begin{abstract}
Norm-Activation model $=\mathrm{d}$
Value-belief norm theory $=\mathrm{e}$

Attitude-behaviour-context theory $=f$
\end{abstract}

Figure 1. Integrated Framework of the behavioural theories to aid understanding of pro-environmental behaviour. Note: We use letters to represent the different pathways (e.g., knowledge-awareness link, awareness-behaviour link, knowledge-behaviour link) hypothesised in each of the theories. 


\subsection{Theory of Reasoned Action (TRA) and the Theory of Planned Behaviour (TPB)}

Proponents of the TRA reason that two factors directly affect people's intentions to act: attitude and subjective norms (referred to as an individual's perception regarding whether people who are important to him or her think if he should perform or not perform the behaviour at hand) and this in turn leads to the performance of the behaviour in question [26]. Closely related to the TRA is the TPB, which integrates the actor's perceived control over the behaviour [27]. TPB looks at 'intentions to behave', and not necessarily actual actions of individuals, and argues that attitudes, subjective norms and perceived behavioural control affect intentions to act and these in turn predict behaviour.

Proponents of these theories acknowledge that the link between belief and behaviour is not straightforward; there are other elements that influence the relationship between the two. However, these models fail to provide clear understanding on the cognitive, normative and affective facets of human behaviour [21]. Additionally, even a positive intention does not necessarily result in pro-environmental behaviour, as this depends on situational factors such as financial ability, time, and available resources, among others [38]. These complex factors make it difficult to predict behaviours relying solely on intentions. However, Bamberg and Moser [22] found strong evidence in support of this model, after their MASEM revealed that indeed attitudes, perceived behavioural control and subjective norms predicted intentions, and intentions in turn predicted behaviours.

\subsection{Norm-Activation Model}

This model was developed to help explain the determinants of moral behaviours: pro-social and altruistic behaviours among people. It is premised on the idea that awareness of the consequences of one's behaviour and ascription of responsibility to self are the main factors that determine personal norm, and this in turn determines whether individuals behave altruistically or not [29,42]. Personal norms, i.e., feelings of moral obligations to carry out specific behaviours, are therefore viewed as direct antecedents of prosocial behaviours and Schwartz rejects the idea of intentions mediating the relationship between personal norm and behaviour. He argues that when people are aware of the consequences of (or not) engaging in specific prosocial behaviours and also ascribe such responsibilities to themselves, they are more likely to act positively. This is probably because personal norms serve as a benchmark for what an individual considers to be proper or improper and may in turn govern the person's behaviour. Subsequently, it is hypothesised that awareness of consequences and ascription of responsibility are not just viewed as fundamental independent variables, but also, moderators of the relationship between personal norm and behaviour [21]. This model however fails to provide insights into how personal norms are derived from the larger social fabric and how socially established measures could drive personal norms and behaviours.

\subsection{Value-Belief-Norm Theory}

The Value-Belief-Norm Theory was proposed as an attempt to modify the Norm Activation Model to reflect the complex connection between values, beliefs, attitudes and norms [30-32]. This theory suggests that values affect beliefs and this in turn affects personal norms, a direct antecedent of pro-environmental behaviour. In this model, Stern argues that endorsement of the new environmental paradigm (NEP) directly predicts awareness of consequences and the extent to which an individual accepts the NEP may reflect a high level of environmental value [30-33]. Subsequently, three major categories of pro-environmental behaviours are identified: environmental citizenship, support for policy and private sphere behaviours.

The Value-Belief-Norm Theory has made a substantial contribution to understanding environmental behaviour, particularly in understanding the key role of values, beliefs and norms in environmentally significant behaviours. Nonetheless, this theory has a major limitation as it overlooks the role of situational factors in actual behaviours [21]. The influence of situational factors (e.g., institutional support or constraint, availability or lack of facilities) in behaviour is key and perhaps explains why 
values explained less than 35\% of variance in general environmental behaviour (and less than $20 \%$ in private sphere behaviours) in Stern et al.'s study [30]. Aside situational factors, it is also possible that environmental values and beliefs may perform better as moderators as opposed to mediators or direct independent variables in explaining behaviour $[13,14,20,43]$.

\subsection{Attitude-Behaviour-Context Theory}

The Attitude-Behaviour-Context ( $\mathrm{ABC}$ ) models behaviour (B) as a complex interactive outcome of intrinsic or 'internal' attitudinal (A) variables and extrinsic or 'external' circumstantial elements (C) [32]. The strength of this model lies in the acknowledgement of the complex structural interaction or dynamics concerning the influence of attitudes (labelled as internal factors) and situational factors (also known as external or contextual factors). It is argued that where situational factors (e.g., monetary incentives and costs, institutional and legal support or constrains, time), play a weak role, the attitude-behaviour link is strong, however, the link is non-existent or weak at best, when situational factors exert a strong influence [21]. This suggests that situational factors moderate the relationship between attitude and behaviour hence, pro-environmental behaviour will be dynamic as situational factors change overtime and in different locations i.e., pro-environmental behaviour may be predisposed to temporal and spatial dynamics.

\section{Materials and Methods}

\subsection{Research Design and Data Collection}

The aim of the present study is to assess the empirical evidence base of the determinants of pro-environmental behaviour predicted by the theories described in Section 2. For this purpose, we adopted a meta-analytic structural equation modelling (MASEM) technique. The first step involved an online search of the literature focussing on the determinants of pro-environmental behaviour (see Figure 2 for an overview of the research design used in this study). We restricted our search to papers written in English and published after 1994, when application of theories to understand pro-environmental behaviour gained considerable momentum [22]. Keywords such as pro-environmental behaviour, pro-ecological behaviour, etc. were applied in multiple search queries to retrieve data from Google Scholar and other academic databases such as Web of Science, Scopus, Business Source Premier, PROQUEST's ABI/INFORM Collection, the Applied Social Sciences Index and Abstracts (ASSIA) and Sociological Abstracts (see Figure 3 for the document selection process and Appendix A for keyword groupings). After applying a follow-up snowball search and removing duplicates, we obtained 387 papers.

Next, we scanned the titles, abstracts and skimmed through the methods sections of the 387 papers with the aim of keeping only papers that contained outputs of "empirical research" as opposed to "reviews", "process-based modelling" or "conceptual papers". After this, there was an intensive reading of methods and result sections of these papers with the aim of retaining only papers that analysed at least one of the relationships of interest e.g., attitude-behaviour link, attitude-intention link, intention-behaviour link (see Figure 1, see also Table 1 for definitions of the variables of interest) and also reported the correlation coefficients and sample sizes as these were needed for the meta-analysis. After this step, 109 papers were retained and used for the meta-analysis (see Appendix B for references of these papers). From Appendix B, it could be observed that the papers analysed cover a wide disciplinary spectrum and are published in a variety of journals. This wide disciplinary spectrum is a strength of the present study and a step towards advancing interdisciplinary approaches to understanding the complexity of pro-environmental behaviour.

As mentioned in Section 1, this study covers a broader range of areas in which pro-environmental behaviour has been studied, beyond just land management. All 109 studies were then grouped under these (four) environmental policy areas based on the focus of the paper: recycling, land management, sustainable consumer behaviour and general ecological behaviour (see Table 2). 
Applying search criteria for literature (see Appendix A for the search terms and combinations )

Applying inclusion and exclusion criteria to screen papers (see Figure 3)

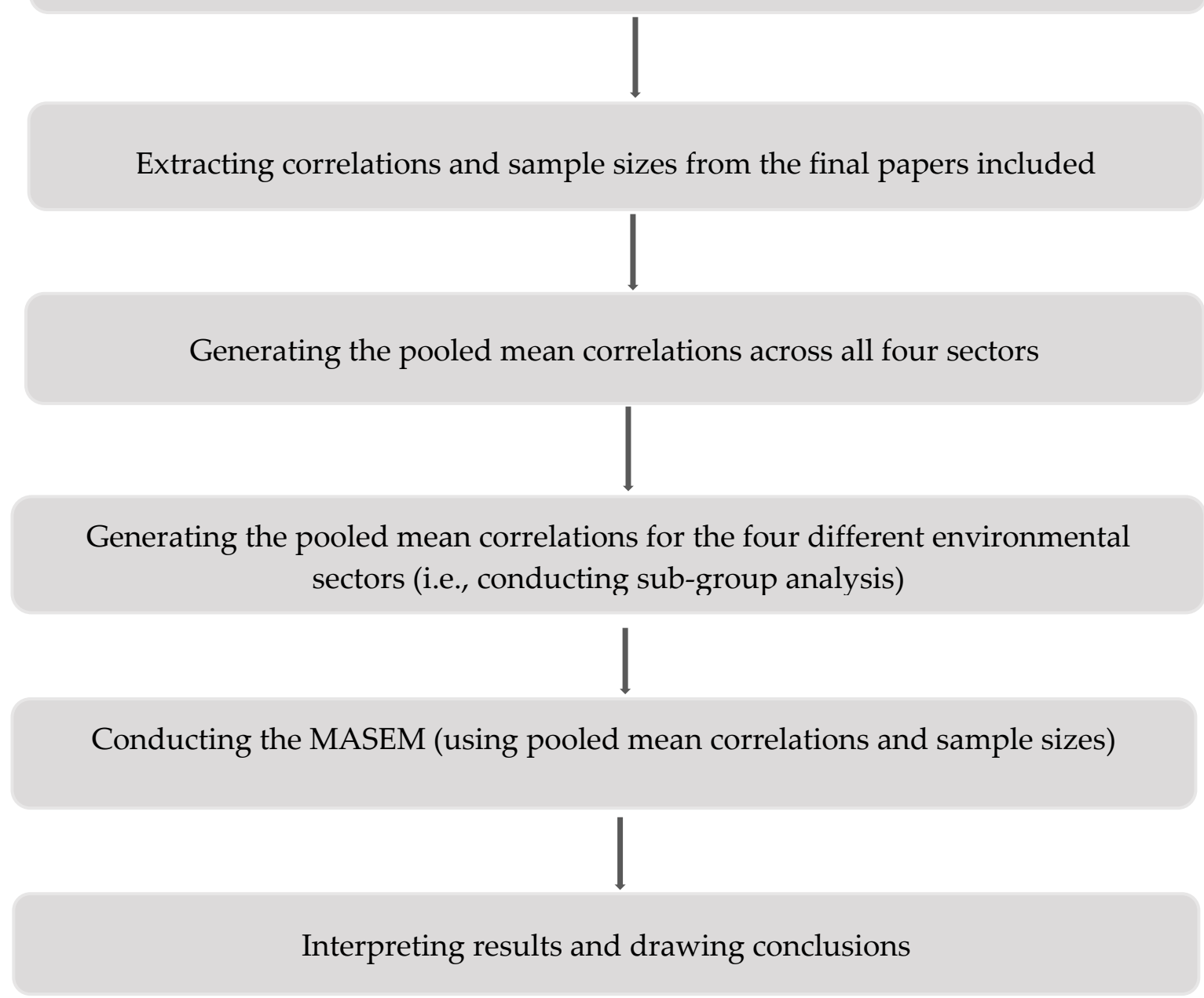

Figure 2. Research design used in this study. 


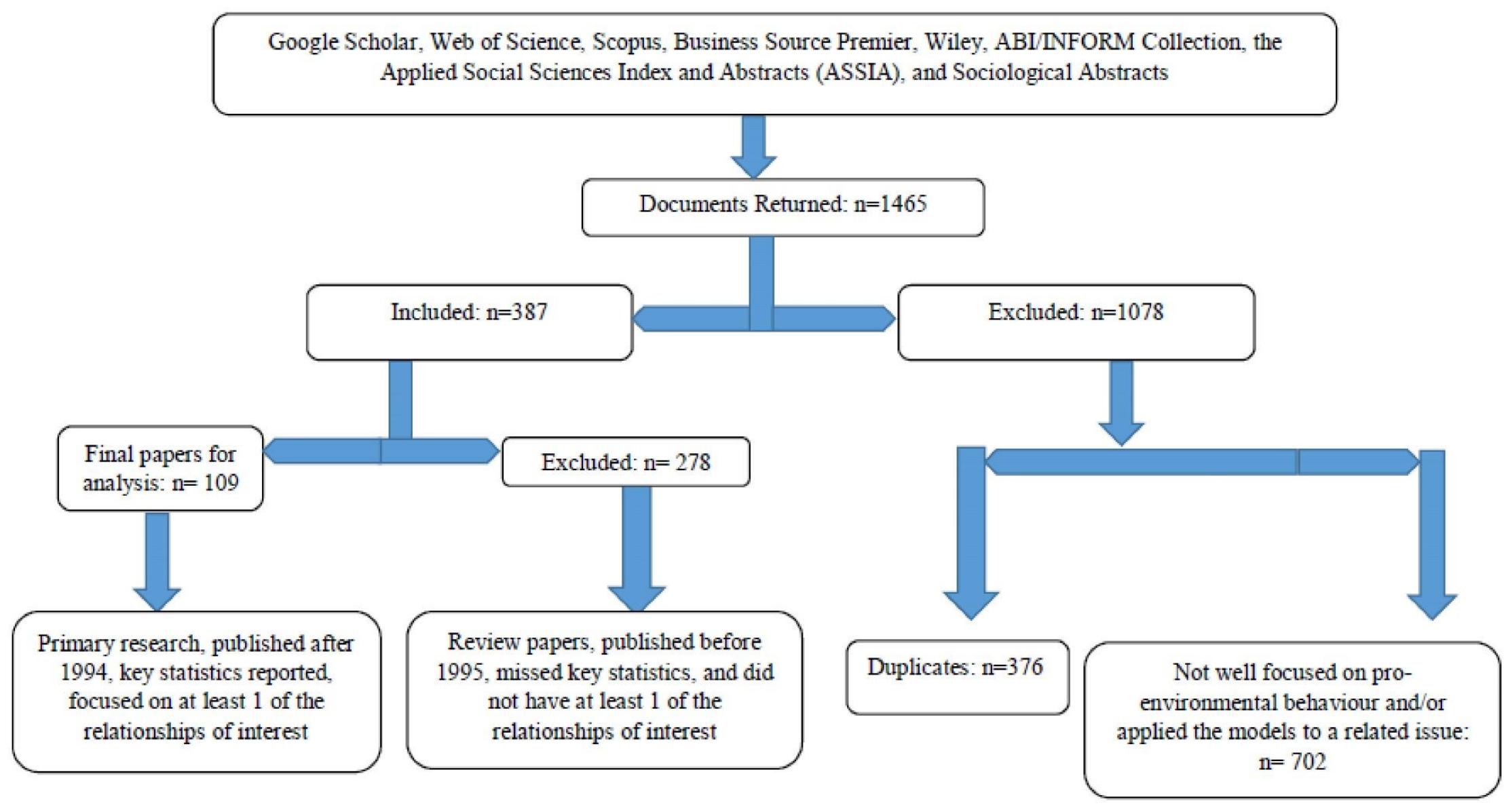

Figure 3. Document Selection Process. 
Table 1. Definitions of study variables.

\begin{tabular}{|c|c|}
\hline Variable & Definition \\
\hline Knowledge & Factual information regarding an environmental problem, action strategy or standard. \\
\hline Beliefs & Perceived knowledge of an environmental problem or action strategy. \\
\hline Awareness & A profound understanding or consciousness of an environmental problem or action strategy. \\
\hline Attitude & A relatively stable feeling about the environment, a problem or an action strategy. \\
\hline Habit & A way of behaving that has become a routine and a relatively stable behavioural pattern, often occurring without pronounced deliberate effort. \\
\hline Intention & An intent or resolve (not) to effect environmentally significant behaviours. \\
\hline Behavioural Willingness & "An openness to risk opportunity—what an individual would be willing to do under various circumstances" [44] \\
\hline Behaviour & Actions, acts or measures that support or result in environmental management gains or at worst causes no harm to the environment. \\
\hline Social Norm & Social or group understandings of what individuals ought to do. \\
\hline Moral Norm & A feeling of moral obligation as opposed to what he perceives that others think [45]. \\
\hline Subjective Norm & Perceptions regarding what others think of him/her concerning a behaviour in question i.e., perceived social pressure. \\
\hline Emotions & Emotions are reactions to an object or a process, and they include both sentimental and cognitive aspects. \\
\hline Self-Efficacy & Self-efficacy is a personal judgement of how well an individual can perform courses of action necessary to deal with prospective situations. \\
\hline Perceived Consequences & Views regarding the outcomes of certain actions or inactions, or an environmental issue. \\
\hline Ascription of Responsibility & Claiming or apportioning responsibility for environmental problems and solutions to self, other individuals or institutions/society. \\
\hline Situational Factors & $\begin{array}{l}\text { Extrinsic factors that contingently facilitate or constrain pro-environmental behaviour. These may include institutional/regulatory support or } \\
\text { constraints, time, farm size, farm type, land tenure system, income, cost of materials, etc. }\end{array}$ \\
\hline Environmental Value & $\begin{array}{l}\text { Refers to a desirable trans-situational goal regarding the environment, ecology, ecosystems or nature that serve as a guiding principle or influence } \\
\text { individuals' environmental behaviours. }\end{array}$ \\
\hline Environmental Concern & An assessment of one's own behaviour, or others' actions with consequences for ecological systems or nature. \\
\hline
\end{tabular}

Table 2. Classification of Papers based on Different Environmental Policy Areas.

\begin{tabular}{ccl}
\hline Number & Issue Area/Broad Focus & Items Covered \\
\hline $\mathbf{1}$ & Recycling & Psycho-social determinants of pro-environmental behaviours related to recycling, public support for recycling support, etc. \\
\hline $\mathbf{2}$ & Land management & The main issues here include sustainable agriculture/conservation, biodiversity, diffuse pollution water quality issues \\
\hline $\mathbf{3}$ & Sustainable consumer behaviour & Green behaviour, sustainable transport modes, renewable and efficient energy use, etc. \\
\hline $\mathbf{4}$ & General ecological behaviour & Cross-cutting issues e.g., climate change or paper discusses issues that cut across two or three of the specific areas above \\
\hline
\end{tabular}




\subsection{Implementing the MASEM}

Meta-analysis is a widely accepted technique for the synthesis of evidence [46]. It is appropriate for this study, since our goal is to establish the quantitative empirical evidence base of the relationships of interest from studies sharing similar hypotheses [46-49]. In this case, it involved pooling the correlation coefficients and samples from the primary studies. Using Hedges and Olkin [50] technique, we calculated the pooled mean correlations and associated $p$-values of the relationships of interest e.g., the attitude-behaviour link, attitude-intention link, intention-behaviour link. This was done through the application of the Comprehensive Meta-Analysis (Version 2) software. Publication bias was assessed using funnel plots [51] which indicated a general absence of publication bias, except for the relationship between intention and environmental concern, which might be biased by not reporting small trials or studies that show non-significant results. We interpreted our results under the random-effects assumption, as heterogeneity test results indicated strong between-study heterogeneity of the pooled correlation matrix ${ }^{2}$ [51]. The random-effect model is an extension of the fixed-effect model where variations in the mean effect across studies are attributed to factors such as differences in location, experimental conditions, and variable type, among others $[49,50,52,53]$.

In an analysis such as this, where the evidence is pooled from multiple sources, it is important to assess the extent to which the statistical significance of the relationships are affected by moderators, i.e., by an additional factor that might contingently impact the statistical significance, direction and/or magnitude of the relationship [54]. Because we used a broad evidence base from different types of environmental behaviours, we tested for the moderating effects of type of environmental behaviour or focus of the primary research through sub-group analysis. Technically, applying sub-group analysis as a meta-regression has advantages as it focusses on differences between multiple groups as appropriate, as opposed to effects in each sub-group separately [55]. A detailed description of how sub-group analysis is applied is presented in [56]. The pooled mean correlation matrix was then fitted onto structural equation models (using AMOS 24) to test the behavioural theories. The structural equation models help to determine the regression weights and associated $p$-values of all the paths hypothesised in the respective theories (see Figure 1).

\section{Results}

\subsection{Overview of the Evidence}

Of the 109 papers studied, only seven focussed on environmentally responsible behaviours related to land management while the most, 52, focussed on sustainable consumer behaviour (Table 3). Table 4 presents the number of retrieved independent primary bivariate correlation coefficients and the respective combined total sample size on which these coefficients are based. This information shows that while some relationships have been commonly studied empirically (e.g., attitude-intention, self-efficacy-intention), others have received little attention (e.g., knowledge-emotion, social norm-ascription of responsibility) and some not studied at all (e.g., habit-behavioural willingness). Table 4 also shows that the awareness-habit link had the smallest (pooled) total sample size $(\mathrm{N}=319)$ while the attitude-self-efficacy link had the largest sample size $(\mathrm{N}=22,390)$.

Table 3. Summary of papers based on different environmental policy areas.

\begin{tabular}{cccc}
\hline Number & Environmental Policy Area & Number of Papers & \% of Total \\
\hline $\mathbf{1}$ & Recycling & 16 & 14.7 \\
$\mathbf{2}$ & Land management & 7 & 6.4 \\
$\mathbf{3}$ & Sustainable consumer behaviour & 52 & 47.7 \\
$\mathbf{4}$ & General ecological behaviour & 34 & 31.2 \\
\hline & Total & 109 & 100.0 \\
\hline
\end{tabular}

2 The $p$-value associated with the Q-statistic and I-squared statistic were significant $(p<0.001)$ with the $\mathrm{I}^{2}$ statistic mostly greater than 80 (Appendix D, see also Appendix C for the $95 \%$ confidence intervals). 
Table 4. Number of independent primary bivariate correlation coefficients and pooled total sample size.

\begin{tabular}{|c|c|c|c|c|c|c|c|c|c|c|c|c|c|c|c|c|c|c|c|}
\hline & VARIABLE & 1 & 2 & 3 & 4 & 5 & 6 & 7 & 8 & 9 & 10 & 11 & 12 & 13 & 14 & 15 & 16 & 17 & 18 \\
\hline 1 & Knowledge & - & & & & & & & & & & & & & & & & & \\
\hline 2 & Beliefs & $\begin{array}{c}\mathrm{K}(4) \\
\mathrm{N}(2739)\end{array}$ & - & & & & & & & & & & & & & & & & \\
\hline 3 & $\begin{array}{l}\text { Awareness or } \\
\text { consciousness }\end{array}$ & $\begin{array}{c}\mathrm{K}(2) \\
\mathrm{N}(523)\end{array}$ & $\begin{array}{c}\mathrm{K}(3) \\
\mathrm{N}(2244\end{array}$ & - & & & & & & & & & & & & & & & \\
\hline 4 & Attitude & $\begin{array}{c}\mathrm{k}(10) \\
\mathrm{N}(5462)\end{array}$ & $\begin{array}{c}\mathrm{K}(7) \\
\mathrm{N}(4455)\end{array}$ & $\begin{array}{c}\mathrm{K}(10) \\
\mathrm{N}(3080)\end{array}$ & - & & & & & & & & & & & & & & \\
\hline 5 & Habit & $\begin{array}{c}\mathrm{K}(1) \\
\mathrm{N}(352)\end{array}$ & & $\begin{array}{c}\mathrm{K}(1) \\
\mathrm{N}(319)\end{array}$ & $\begin{array}{c}\mathrm{K}(4) \\
\mathrm{N}(1597)\end{array}$ & - & & & & & & & & & & & & & \\
\hline 6 & Intention & $\begin{array}{c}\mathrm{K}(8) \\
\mathrm{N}(4401)\end{array}$ & $\begin{array}{c}\mathrm{K}(4) \\
\mathrm{N}(2889)\end{array}$ & $\begin{array}{c}\mathrm{K}(13) \\
\mathrm{N}(4746)\end{array}$ & $\begin{array}{c}\mathrm{K}(46) \\
\mathrm{N}(21,886)\end{array}$ & $\begin{array}{c}\mathrm{K}(5) \\
\mathrm{N}(1563)\end{array}$ & - & & & & & & & & & & & & \\
\hline 7 & Behavioural willingness & $\begin{array}{c}\mathrm{K}(5) \\
\mathrm{N}(1222) \\
\end{array}$ & $\begin{array}{c}\mathrm{K}(1) \\
\mathrm{N}(1467) \\
\end{array}$ & $\begin{array}{c}\mathrm{K}(6) \\
\mathrm{N}(2353) \\
\end{array}$ & $\begin{array}{c}\mathrm{K}(4) \\
\mathrm{N}(1060)\end{array}$ & 0 & $\begin{array}{c}\mathrm{K}(4) \\
\mathrm{N}(911) \\
\end{array}$ & - & & & & & & & & & & & \\
\hline 8 & Behaviour & $\begin{array}{c}\mathrm{K}(9) \\
\mathrm{N}(4106)\end{array}$ & $\begin{array}{c}\mathrm{K}(7) \\
\mathrm{N}(12,828)\end{array}$ & $\begin{array}{c}\mathrm{K}(17) \\
\mathrm{N}(7694)\end{array}$ & $\begin{array}{c}\mathrm{K}(30) \\
\mathrm{N}(18,078)\end{array}$ & $\begin{array}{c}\mathrm{K}(4) \\
\mathrm{N}(1493)\end{array}$ & $\begin{array}{c}\mathrm{K}(29) \\
\mathrm{N}(10,805)\end{array}$ & $\begin{array}{c}\mathrm{K}(5) \\
\mathrm{N}(1498)\end{array}$ & - & & & & & & & & & & \\
\hline 9 & Social norm & $\begin{array}{c}\mathrm{K}(2) \\
\mathrm{N}(627)\end{array}$ & & $\begin{array}{c}\mathrm{K}(2) \\
\mathrm{N}(751)\end{array}$ & $\begin{array}{c}\mathrm{K}(6) \\
\mathrm{N}(4621)\end{array}$ & & $\begin{array}{c}\mathrm{K}(9) \\
\mathrm{N}(6557)\end{array}$ & & $\begin{array}{c}\mathrm{K}(9) \\
\mathrm{N}(2658)\end{array}$ & - & & & & & & & & & \\
\hline 10 & Moral norm & $\begin{array}{c}\mathrm{K}(1) \\
\mathrm{N}(352)\end{array}$ & & $\begin{array}{c}\mathrm{K}(1) \\
\mathrm{N}(316)\end{array}$ & $\begin{array}{c}\mathrm{K}(9) \\
\mathrm{N}(5415)\end{array}$ & & $\begin{array}{c}\mathrm{K}(7) \\
\mathrm{N}(3132)\end{array}$ & & $\begin{array}{c}\mathrm{K}(3) \\
\mathrm{N}(1462)\end{array}$ & & - & & & & & & & & \\
\hline 11 & Subjective norm & $\begin{array}{c}\mathrm{K}(2) \\
\mathrm{N}(2202)\end{array}$ & & $\begin{array}{c}\mathrm{K}(6) \\
\mathrm{N}(1944)\end{array}$ & $\begin{array}{c}\mathrm{K}(42) \\
\mathrm{N}(22,242)\end{array}$ & & $\begin{array}{c}\mathrm{K}(33) \\
\mathrm{N}(15,355)\end{array}$ & & $\begin{array}{c}\mathrm{K}(20) \\
\mathrm{N}(8676)\end{array}$ & & & - & & & & & & & \\
\hline 12 & Emotions & $\begin{array}{c}\mathrm{K}(1) \\
\mathrm{N}(321) \\
\end{array}$ & & $\begin{array}{c}\mathrm{K}(10) \\
\mathrm{N}(3653)\end{array}$ & $\begin{array}{c}\mathrm{K}(6) \\
\mathrm{N}(2286)\end{array}$ & & $\begin{array}{c}\mathrm{K}(13) \\
\mathrm{N}(5323)\end{array}$ & & & $\begin{array}{c}\mathrm{K}(5) \\
\mathrm{N}(1777) \\
\end{array}$ & $\begin{array}{c}\mathrm{K}(6) \\
\mathrm{N}(2420)\end{array}$ & & - & & & & & & \\
\hline 13 & Self-efficacy & $\begin{array}{c}\mathrm{K}(4) \\
\mathrm{N}(3377)\end{array}$ & & $\begin{array}{c}\mathrm{K}(6) \\
\mathrm{N}(2158)\end{array}$ & $\begin{array}{c}\mathrm{K}(37) \\
\mathrm{N}(22,390) \\
\end{array}$ & $\begin{array}{c}\mathrm{K}(2) \\
\mathrm{N}(1079)\end{array}$ & $\begin{array}{c}\mathrm{K}(39) \\
\mathrm{N}(19,528) \\
\end{array}$ & $\begin{array}{c}\mathrm{K}(6) \\
\mathrm{N}(1809)\end{array}$ & $\begin{array}{c}\mathrm{K} 23) \\
\mathrm{N}(9822) \\
\end{array}$ & $\begin{array}{c}\mathrm{K}(4) \\
\mathrm{N}(1733)\end{array}$ & $\begin{array}{c}\mathrm{K}(5) \\
\mathrm{N}(3472)\end{array}$ & $\begin{array}{c}\mathrm{K}(9) \\
\mathrm{N}(8757)\end{array}$ & & - & & & & & \\
\hline 14 & Perceived consequences & $\begin{array}{c}\mathrm{K}(3) \\
\mathrm{N}(971)\end{array}$ & & $\begin{array}{c}\mathrm{K}(6) \\
\mathrm{N}(1479)\end{array}$ & $\begin{array}{c}\mathrm{K}(10) \\
\mathrm{N}(3346)\end{array}$ & & $\begin{array}{c}\mathrm{K}(19) \\
\mathrm{N}(6402)\end{array}$ & & $\begin{array}{c}\mathrm{K}(12) \\
\mathrm{N}(4324)\end{array}$ & $\begin{array}{c}\mathrm{K}(3) \\
\mathrm{N}(1181)\end{array}$ & $\begin{array}{c}\mathrm{K}(12) \\
\mathrm{N}(6684)\end{array}$ & & & & - & & & & \\
\hline 15 & $\begin{array}{l}\text { Ascription of } \\
\text { responsibility }\end{array}$ & & & $\begin{array}{c}\mathrm{K}(3) \\
\mathrm{N}(493)\end{array}$ & $\begin{array}{c}\mathrm{K}(5) \\
\mathrm{N}(1314)\end{array}$ & & $\begin{array}{c}\mathrm{K}(8) \\
\mathrm{N}(2907)\end{array}$ & & $\begin{array}{c}\mathrm{K}(6) \\
\mathrm{N}(2006)\end{array}$ & $\begin{array}{c}\mathrm{K}(2) \\
\mathrm{N}(676)\end{array}$ & & $\begin{array}{c}\mathrm{K}(3) \\
\mathrm{N}(974)\end{array}$ & & & & - & & & \\
\hline 16 & $\begin{array}{l}\text { Situational factors e.g., } \\
\text { time, institutional support }\end{array}$ & & & & & & $\begin{array}{c}\mathrm{K}(9) \\
\mathrm{N}(3097)\end{array}$ & & $\begin{array}{c}\mathrm{K}(11) \\
\mathrm{N}(5194)\end{array}$ & & & & & & & & - & & \\
\hline 17 & Environmental value & $\begin{array}{c}\mathrm{K}(2) \\
\mathrm{N}(762)\end{array}$ & & & $\begin{array}{c}\mathrm{K}(2) \\
\mathrm{N}(590) \\
\end{array}$ & & $\begin{array}{c}\mathrm{K}(7) \\
\mathrm{N}(2494)\end{array}$ & & & & & & & & & & & - & \\
\hline 18 & Environmental concern & $\begin{array}{c}\mathrm{K}(4) \\
\mathrm{N}(1103)\end{array}$ & & & $\begin{array}{c}\mathrm{K}(7) \\
\mathrm{N}(2743)\end{array}$ & & $\begin{array}{c}\mathrm{K}(11) \\
\mathrm{N}(4404)\end{array}$ & & & & & & & & & & & & - \\
\hline
\end{tabular}

$\mathrm{K}$ = Number of independent correlation coefficients obtained from reviewed papers and $\mathrm{N}$ = total sample size from respective $\mathrm{K}$. 


\subsection{Pooled Mean Correlation Analysis}

Pooled mean correlations of the relationships analysed are presented in Table 5. The strongest association was found between awareness of problem and/or action strategies and perceived consequences of individual's actions/inactions ( $\mathrm{r}=0.67 ; p<0.01 ; \mathrm{N}=1479 ; 6$ studies). This indicates that people who are aware of an environmental problem (e.g., diffuse pollution) and action strategies (e.g., best land management practices) are more likely to perceive associated consequences of (not) engaging in that practice. The second strongest relationship was found between moral norm and environmental attitude ( $\mathrm{r}=0.62 ; p<0.01 ; \mathrm{N}=5415 ; 9$ studies), indicating that individuals who feel a moral obligation to behave in an environmentally responsible manner are more likely to report a positive environmental attitude. On the contrary, the weakest (but still statistically significant) relationships were found between habit and environmental awareness $(\mathrm{r}=0.02 ; p<0.01 ; \mathrm{N}=319$; 1 study) and between habit and attitude ( $\mathrm{r}=0.03 ; p<0.01 ; \mathrm{N}=1597 ; 4$ studies). There were a few associations (e.g., emotions-attitude) for which results indicated no significant relationship.

Results also indicate a strong between-study heterogeneity (Appendix D), which is partly attributable to the different environmental policy areas that the studies address (Table 6). For instance, while an overall correlation of $r=0.21$ was recorded for the relationship between environmental awareness and behaviour, results varied between different environmental policy areas: it was slightly stronger $(r=0.23 ; p<0.05)$ in sustainable consumer behaviour, slightly weaker $(r=0.20$; $p<0.05)$ in general ecological behaviour, but it was non-significant $(p>0.05)$ in recycling and land management behaviours.

\subsection{Meta-analytic Structural Equation Modelling}

Results of the MASEM that were used to test the predicted paths of the theories under consideration (see Figure 4) are presented in Table 7. First, we evaluated the fit of the models using a combination of recommended fit indices. When model fit indices such as the Normed Fit Index and the Comparative Fit Index ${ }^{3}$ are greater than 0.95 , it shows that the model fits the data very well $[57,58]$. Based on this criterion, all theories fitted the data with the exception of the Value-Belief-Norm Theory and Norm Activation Model. Results of the paths hypothesised by the behavioural theories for which we obtained acceptable fits (Table 7) are presented in Table 8. They indicate that almost all predictions of the theories are statistically significant with the exception of the knowledge-awareness pathway for Persuasion Theory and the subjective norm-intention link for Theories of Reasoned Action and Planned Behaviour.

Results in Table 8 further indicate that the evidence supports the postulation that awareness affects attitude (56\% of the variance explained) and attitude in turn affects pro-environmental behaviour ( $49 \%$ of the variance explained) in line with the Persuasion Theory. Also, the results support the hypotheses of the Theory of Reasoned Action: we found that attitude predicts intention (78\% of variance explained) and intentions in turn predict behaviour ( $74 \%$ of variance explained). Furthermore, our results confirm the postulations of the Theory of Planned Behaviour as intentions mediate the relationship between factors such as attitude, subjective norms and perceived behaviour control (referred to as self-efficacy in the present study) and pro-environmental behaviour ( $76 \%$ of variance explained). Overall, there is strong evidence from the MASEM supporting the majority of the theoretical frameworks under consideration.

3 Although the chi square appears to be a traditional measure for assessing overall model fit [57], we do not rely on it. This is because it is susceptible to sample size, thus, unlikely to accurately differentiate between an acceptable fitting model and a poor one. We therefore rely on the Normed Fit Index (NFI) and the Comparative Fit Index (CFI). This combination helps us to overcome problems of sample size susceptibility, as the CFI is least affected by the sample size [57]. 
Table 5. Pooled correlations for all environmental policy areas.

\begin{tabular}{|c|c|c|c|c|c|c|c|c|c|c|c|c|c|c|c|c|c|c|c|}
\hline SN & Construct & 1 & 2 & 3 & 4 & 5 & 6 & 7 & 8 & 9 & 10 & 11 & 12 & 13 & 14 & 15 & 16 & 17 & 18 \\
\hline 1 & Knowledge & - & & & & & & & & & & & & & & & & & \\
\hline 2 & Beliefs & 0.51 & - & & & & & & & & & & & & & & & & \\
\hline 3 & Awareness & 0.25 & 0.16 & - & & & & & & & & & & & & & & & \\
\hline 4 & Attitude & 0.36 & 0.52 & 0.31 & - & & & & & & & & & & & & & & \\
\hline 5 & Habit & $0.22 \mathrm{a}$ & & $0.02 \mathrm{a}$ & 0.03 & - & & & & & & & & & & & & & \\
\hline 6 & Intention & 0.40 & 0.42 & 0.41 & 0.53 & 0.12 & - & & & & & & & & & & & & \\
\hline 7 & Behavioural willingness & 0.27 & $0.23 \mathrm{a}$ & 0.39 & 0.20 & 0 & 0.43 & - & & & & & & & & & & & \\
\hline 8 & Behaviour & 0.28 & 0.24 & 0.22 & 0.37 & 0.28 & 0.44 & 0.34 & - & & & & & & & & & & \\
\hline 9 & Social norm & 0.22 & & 0.29 & 0.37 & & 0.42 & & 0.42 & - & & & & & & & & & \\
\hline 10 & Moral norm & 0.23 & & 0.41 & 0.62 & & 0.48 & & 0.36 & & - & & & & & & & & \\
\hline 11 & Subjective norm & 0.57 & & 0.40 & 0.45 & & 0.43 & & 0.25 & & & - & & & & & & & \\
\hline 12 & Emotions & $0.45 \mathrm{a}$ & & 0.24 & $0.28 \mathrm{NS}$ & & 0.38 & & & $0.11 \mathrm{NS}$ & $0.18 \mathrm{NS}$ & & - & & & & & & \\
\hline 13 & Self-efficacy & 0.18 & & 0.32 & 0.39 & 0.28 & 0.49 & 0.39 & 0.27 & 0.31 & 0.47 & 0.31 & & - & & & & & \\
\hline 14 & Perceived consequences & 0.22 & & 0.67 & 0.42 & & 0.38 & & 0.15 & 0.18 & 0.49 & & & & - & & & & \\
\hline 15 & Ascription of responsibility & & & 0.41 & 0.37 & & 0.51 & & 0.23 & 0.35 & & 0.47 & & & & - & & & \\
\hline 16 & Situational factors & & & & & & $-0.02 \mathrm{NS}$ & & $-0.07 \mathrm{NS}$ & & & & & & & & - & & \\
\hline 17 & Environmental value & 0.40 & & & 0.42 & & 0.39 & & & & & & & & & & & - & \\
\hline 18 & Environmental concern & 0.30 & & & 0.24 & & 0.30 & & & & & & & & & & & & - \\
\hline
\end{tabular}

Note: Correlations under random-effects assumption; $\mathrm{a}=$ no pooled correlation (i.e, only one correlation was retrieved); NS = non-significant relationship (all other $\mathrm{r}$ values are significant at the $p \leq 0.05$ ). We combined the locus of control and perceived behavioural control as self-efficacy due to limited data. 
Table 6. Pooled correlations across different environmental policy areas.

\begin{tabular}{|c|c|c|c|}
\hline Group & Correlation & Lower Limit & Upper Limit \\
\hline \multicolumn{4}{|c|}{ Awareness-behaviour relationship } \\
\hline Recycling & 0.12 & -0.35 & 0.55 \\
\hline Land management & 0.25 & -0.22 & 0.62 \\
\hline Sustainable consumer behaviour & $0.23^{* *}$ & 0.07 & 0.37 \\
\hline General ecological behaviour & $0.20 *$ & 0.00 & 0.38 \\
\hline Overall & $0.21^{* *}$ & 0.10 & 0.32 \\
\hline \multicolumn{4}{|c|}{ Attitude-behaviour relationship } \\
\hline Recycling & 0.12 & -0.35 & 0.55 \\
\hline Land management & 0.25 & -0.22 & 0.62 \\
\hline Sustainable consumer behaviour & $0.23^{* *}$ & 0.07 & 0.37 \\
\hline General ecological behaviour & $0.20 *$ & 0.00 & 0.38 \\
\hline Overall & $0.21 * *$ & 0.10 & 0.32 \\
\hline \multicolumn{4}{|c|}{ Intention-behaviour relationship } \\
\hline Recycling & $0.61^{* *}$ & 0.41 & 0.76 \\
\hline Land management & $0.07 \mathrm{a}$ & -0.01 & 0.15 \\
\hline Sustainable consumer behaviour & $0.47^{* *}$ & 0.31 & 0.60 \\
\hline General ecological behaviour & $0.40^{* *}$ & 0.30 & 0.49 \\
\hline Overall & $0.23^{* *}$ & 0.18 & 0.29 \\
\hline \multicolumn{4}{|c|}{ Self-efficacy-behaviour relationship } \\
\hline Recycling & $0.44^{* *}$ & 0.27 & 0.59 \\
\hline Land management & 0.23 * & 0.01 & 0.42 \\
\hline Sustainable consumer behaviour & $0.32 * *$ & 0.18 & 0.45 \\
\hline General ecological behaviour & $0.18^{* *}$ & 0.04 & 0.32 \\
\hline Overall & $0.28^{* *}$ & 0.20 & 0.36 \\
\hline \multicolumn{4}{|c|}{ Subjective norm-behaviour relationship } \\
\hline Recycling & $0.18^{* *}$ & 0.05 & 0.30 \\
\hline Land management & 0.33 & -0.26 & 0.74 \\
\hline Sustainable consumer behaviour & $0.33^{* *}$ & 0.18 & 0.46 \\
\hline General ecological behaviour & 0.07 & -0.12 & 0.26 \\
\hline Overall & $0.21 * *$ & 0.12 & 0.29 \\
\hline
\end{tabular}

Notes: ${ }^{* *} p \leq 0.01 ; * p \leq 0.05 ;$ a $=$ just 1 correlation retrieved. 


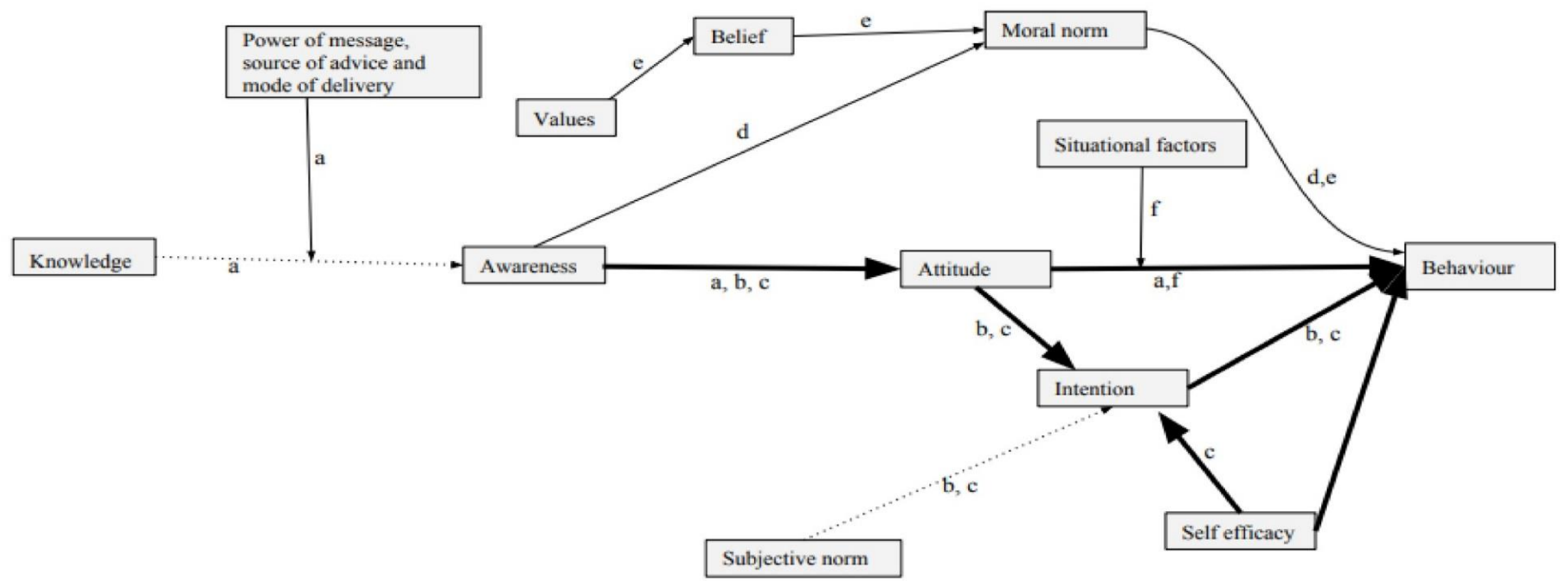

Key

\section{Persuasion Theory $=a$}

Theory of Planned Behaviour $=\mathrm{b}$

Theory of reasoned action $=\mathrm{c}$
Norm-Activation model $=\mathrm{d}$

Value-belief norm theory $=\mathrm{e}$

Attitude-behaviour-context theory $=f$

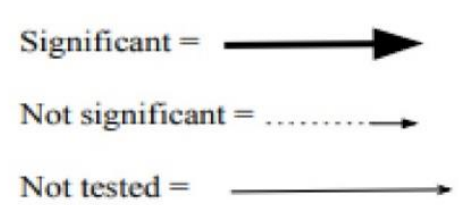

Figure 4. Integrated Framework of paths tested under the different theories. Note: We use letters to represent the different pathways (e.g., knowledge-awareness link, awareness-behaviour link, knowledge-behaviour link) hypothesised in each of the theories. 
Table 7. Model fit indices.

\begin{tabular}{ccccc}
\hline Theories & DF & NFI & CFI & Judgement \\
\hline Persuasion Theory & 3 & 1.0 & 1.0 & Good fit \\
\hline Theory of Reasoned Action & 3 & 1.0 & 1.0 & Good fit \\
\hline Theory of Planned Behaviour & 5 & 1.0 & 1.0 & Good fit \\
\hline Norm Activation Model & 2 & - & - & Poor fit \\
\hline Value-Belief-Norm Model & 2 & - & 0.0 & Poor fit \\
\hline Attitude-Behaviour-Context (ABC) Model & 0 & 1.0 & 1.0 & Good fit \\
\hline
\end{tabular}

$\mathrm{DF}=$ Degrees of freedom; NFI = Normed Fit Index; CFI = Comparative Fit Index.

Table 8. Results of regression paths.

\begin{tabular}{|c|c|c|c|c|}
\hline $\begin{array}{l}\text { Independent } \\
\text { Variable }\end{array}$ & $\begin{array}{l}\text { Dependent } \\
\text { Variable }\end{array}$ & Estimate & $\begin{array}{l}\text { Standard } \\
\text { Error }\end{array}$ & $\begin{array}{c}\text { Total Explained } \\
\text { Variance }\end{array}$ \\
\hline \multicolumn{5}{|c|}{ Persuasion Theory } \\
\hline Knowledge & Awareness & -0.1 & 0.4 & - \\
\hline Awareness & Attitude & $0.8^{* * *}$ & 0.2 & 0.56 \\
\hline Attitude & Behaviour & $0.7^{* * *}$ & 0.1 & 0.49 \\
\hline \multicolumn{5}{|c|}{ Theory of Reasoned Action } \\
\hline Attitude & Intention & $0.9 * * *$ & 0.1 & 0.78 \\
\hline Subjective norm & Intention & -0.2 & 0.3 & - \\
\hline Intention & Behaviour & $0.9 * * *$ & 0.1 & 0.74 \\
\hline \multicolumn{5}{|c|}{ Theory of Planned Behaviour } \\
\hline Attitude & Intention & $0.7^{* * *}$ & 0.1 & $0.77 \mathrm{a}$ \\
\hline Subjective norm & Intention & 0.3 & 0.2 & - \\
\hline Self-efficacy & Intention & $0.5^{* * *}$ & 0.1 & $0.77 \mathrm{a}$ \\
\hline Self-efficacy & Behaviour & $-0.4^{* * *}$ & 0.1 & $0.76 \mathrm{a}$ \\
\hline Intention & Behaviour & $1.0^{* * *}$ & 0.1 & $0.76 \mathrm{a}$ \\
\hline \multicolumn{5}{|c|}{ Attitude-Behaviour-Context (ABC) Theory } \\
\hline Attitude & Behaviour & $0.7^{* * *}$ & 0.1 & 0.49 \\
\hline
\end{tabular}

Notes: ${ }^{* * *} p<0.001 ;{ }^{* *} p<0.01 ;{ }^{*} p<0.05 ; \mathrm{a}=$ cumulative effect of two or more variables. Path results for Value-Belief-Norm and Norm Activation Models were excluded as data did not fit models.

\section{Discussion}

The results of our meta-analysis indicate that almost all the pooled correlations between variables were significant but the strength of the relationships are mainly weak to moderate. The strongest association was found between awareness (of problem and/or action strategies) and perceived consequences of individual's actions. This finding is unsurprising, as people who are conscious of an environmental problem (e.g., diffuse water pollution from agriculture) and best management practices are more likely to be concerned with the consequences of engaging in practices that could cause or induce such environmental problems $[9,14,20]$. Results from the MASEM show that most of the paths hypothesised in the Theories of Planned Behaviour and Reasoned Action, Attitude-Behaviour-Context Model, and the Persuasion Theory are supported by evidence from the literature. For instance, the link between attitudes and intentions, and intentions and behaviours (in the Theory of Planned Behaviour) are supported. This suggests that people with strong pro-environmental attitudes are more likely 
to have positive intentions to engage in pro-environmental behaviour, and this in turn can result in uptake of best management practices.

Although generally the evidence supports the theoretical frameworks, there were a few cases where results indicated non-significant relationships. For instance, the knowledge-awareness link predicted in the Persuasion Theory was non-significant. This implies that having access to knowledge or environmental management information does not automatically guarantee environmental awareness as this may depend on factors such as environmental concern, emotions, experience, information source, message framing and delivery $[6,7,37]$. Indeed, proponents of the Persuasion Theory acknowledge that the link between knowledge and awareness depends on some of these factors; however, in the present study, we were unable to confirm this due to a lack of quantitative data or limited data on these variables in the literature. Nonetheless, qualitative evidence from land management studies (e.g., $[4,6,9,59])$ has indeed indicated that experience, knowledge networks, advice source and nature plays a key role in land managers' awareness and uptake of best management practices (specifically diffuse pollution mitigation measures).

The MASEM suggests that the Value-Belief-Norm Theory and the Norm Activation Model were not supported by the data. The lack of evidence supporting their framing may be due to the neglect of situational factors (which this study was unable to confirm due to data limitation) in these two theories and their reductionist approach (i.e., the emphasis placed on altruistic factors). Pro-environmental behaviour is complex, as many decisions and actions are influenced by self-interest and situational factors. For instance, in land management, while a farmer may be willing to engage in an environmentally sustainable practice, cost of compliance, income forgone and 'goodness of fit' of agri-environment schemes are key players of the ultimate decision and action [7,18,37,40,60]. Evidence suggests that for those policies that achieved significant successes (e.g., the National Landcare Programme, Monitor Farms Programme, Diffuse Pollution Management Strategy), success depended greatly on contextual factors such as the financial incentives given to farmers, identifying trusted sources which exert the greatest social pressure on farmers (e.g., friends, advisors, family), presenting optimistic messages and highlighting benefits to farmers $[9,14]$. Perhaps this could explain why policies (e.g., the Vietnamese Government Forest Conservation Policy) that place little emphasis on such situational factors are less likely to succeed in triggering positive behaviours [61] and also why we did not find statistical evidence in the present study to support some of these models. Additionally, situational factors are predisposed to temporal and spatial dynamics [32], hence, future research in land management could examine these models considering the peculiarities of different spatial and temporal factors (such as how much time is needed for farmers to adopt different best land management practices and how much does one's location influence such decisions). Further, future research could focus on unpacking the complex interaction between the variables explored in this study and other potential factors such as land managers' demographic characteristics, and how that influence their behaviours. A deeper understanding of these interactions could further contribute to designing effective policies to encourage positive behavioural change amongst farmers.

Another important finding is that there is a strong between-study heterogeneity, which is partly attributable to the type of environmental behaviour which the different studies address [22,55,62]. That is, results for the same model varied in terms of statistical significance and strength of association for different environmental behaviours. For instance, results for the relationship between environmental awareness and behaviour indicated that this relationship was slightly stronger in sustainable consumer behaviour and slightly weaker in general ecological behaviour, but it was non-significant in recycling and land management behaviours. This is an important finding because it would preclude the validity of directly transferring recommendations across sectors (i.e., what is valid for recycling in terms of promoting behaviours might not be successful in trying to promote uptake of best land management practices). Therefore, policy recommendations should be tailored to the specific environmental issues. This is because models of pro-environmental behaviour will yield varying levels of predictive capacity or effectiveness for different environmental behaviours; hence, a critical evaluation should be undertaken in 
order to select which models are more suitable for understanding a particular environmental behaviour (e.g., best land management practices) while paying attention to the different conditions in which a particular model is the most useful [38].

We now turn to discuss potential limitations of our study. It must be noted that most of the primary studies used a self-reported approach in measuring the variables under study (e.g., attitudes and behaviour). Self-reported studies are usually impacted by social desirability bias, memory bias and variation in survey participants' environmental knowledge and beliefs $[63,64]$. This can potentially introduce estimation errors in the results of the primary studies, and by extension, the results of this meta-analysis. Additionally, we are aware of the fact that meta-analysis of relationships involves some form of data aggregation (e.g., lots of different actions which may be affected by other variables are being pooled together and generically referred to as 'behaviour') which could be faced with issues of ecological confounding [55,64]. As a result, we treat non-significant relationships as tentative cases requiring further investigation in primary research rather than as an absence of true relationships.

Another limitation lies in the fact that the MASEM used a correlation matrix instead of a covariance matrix as input. This could potentially result in unreliable/incorrect Chi square statistics and standard errors [22,56]. Furthermore, the MASEM was based on correlations, not covariance, which could result in overestimation of some parameters due to problems of multicollinearity (as can be observed from the results for the intention-behaviour link of the TPB model). Finally, the subgroup analysis relied on correlation coefficients and not regression coefficients, and also used a dichotomous method. This may result in the loss of valuable information, as it fails to take account of the complex nature of data from the different primary studies [56]. We entreat readers to consider these limitations when interpreting our results, while encouraging future studies to take account of study-level variables as continuous covariates in the application of MASEM.

The final limitation stems from the variation in the number of papers (from the different environmental policy areas) and the unequal sample sizes. For instance, only seven papers were drawn from the land management sector (probably due to the restriction to only papers that reported correlations and sample sizes). This could have impacted the statistical analysis. Also, removing qualitative studies and papers that do not report correlations and sample sizes could limit our understanding of the 'true' relationships between variables reported across the different environmental sectors. It is also important to note that although we attempted to reduce the possibility of missing relevant papers by using the snowball technique, it is possible that we still missed a few key papers. Nonetheless, the results provide insights into the significant variation in relationships studied across the different environmental policy areas.

\section{Concluding Remarks}

Land management policies are increasingly emphasising behavioural change as a means to improve environmental management outcomes. This is based, implicitly or explicitly, on theories that suggest that pro-environmental behaviour can be predicted and altered based on certain factors (referred to as determinants of pro-environmental behaviour), and that behavioural changes, in turn, can be expected to lead to improved environmental outcomes (such as water quality, soil health, biodiversity loss) through the adoption of mitigation measures or reduction of impactful activities. This assumes the existence of a straightforward pathway linking the determinants of behaviour to pro-environmental behaviour and then to environmental outcomes. However, studies examining the determinants of pro-environmental behaviour have found mixed evidence. Establishing whether existing evidence supports the postulations of such theories (in aggregate terms) could help provide answers that may trigger new policy directions. It is therefore important that these theories are revisited to assess if the evidence supports their postulations so that a more robust knowledge base can be established to inform land management policies. In this study, we conducted such analysis. By using meta-analytic structural equation modelling (MASEM), we expanded on previous reviews because the method allows us to test the mechanisms through which these different variables affect one 
another, which previous studies relying on correlations and multiple regressions were unable to reveal. Moreover, although we focus on land management, the evidence base that we explore goes beyond that of land management only, including related areas and general ecological behaviours more broadly.

Our findings suggest a strong evidence base for the Persuasion Theory, Theory of Reasoned Action, Theory of Planned Behaviour and the Attitude-Behaviour-Context (ABC) Model. In contrast, evidence supporting the Value-Belief-Norm Theory and the Norm Activation Model is less established. The lack of evidence supporting the Value-Belief-Norm Theory and the Norm Activation Model suggests the need to include situational factors in models of pro-environmental behaviour (and by extension, environmental policies that are implicitly or explicitly based on such models). Including such variables could improve our understanding of the complex determinants of pro-environmental behaviour, and this may in turn, help adjust policies to address various motivations, capabilities and circumstances of stakeholders (e.g., farmers). From a research perspective, qualitative methods could be used to gather rich data that provides a deeper understanding of the determinants of pro-environmental behaviour and how best to influence stakeholders' behaviour.

The results also indicate that type of environmental policy area (e.g., recycling, land management) moderates the relationships between the different variables and therefore the underlying assumptions might not be shared across fields. This has key policy implications as while lessons can be learnt from other environmental areas, land management policies aimed at influencing behaviours will need to be tailored to the specific context rather than simply 'imported' from other areas. Therefore, models upon which policies may (implicitly/explicitly) be based need to consider context-specific nuances. Such context-specific policies may encourage uptake of pro-environmental behaviours. This does not pre-empt, however, the need for the assessment of the full pathway, i.e., including also the assessment of the effectiveness of changes in behaviour on environmental outcomes [14]. This study has attempted to investigate the first component of the pathway: the path linking psycho-social factors to pro-environmental behaviour, which is a contribution towards understanding the effects of policies on uptake of pro-environmental behaviours. We encourage future research to explore the full pathway drawing both on psychosocial and biophysical data.

Author Contributions: This research was conceived by M.O., with the guidance of J.M.-O., P.N. and P.J.C. Data extraction, formal analysis, interpretation of results, and preparation of original draft were carried out by M.O. with inputs from J.M.-O., P.N. and P.J.C. All authors have read and agreed to the published version of the manuscript.

Funding: This research was funded by the University of Leeds International Doctoral Scholarship (LIDS) (2017-2020 and the RePhoKUs project (The role of phosphorus in the sustainability and resilience of the UK food system) funded by BBSRC, ESRC, NERC and the Scottish Government under the UK Global Food Security research programme (Grant No. BB/R005842/1).

Acknowledgments: Many thanks to Ata Senior Yeboah, Amponsah Abraham, Jefim Vogel and John K.B. Kwatia for their advice and support of this work.

Conflicts of Interest: The authors declare no conflict of interest.

\section{Appendix A Search Terms and Groupings}

As terms such as "pro-environmental behaviour" and "theories" are sometimes expressed differently, we used substitute words to help capture the fullness of the terms as well as wildcard symbols (e.g., asterisks) to capture the variations of the words (see samples below):

Search 1. Variations of Pro-environmental behaviour and the theories.

Level 1: one of the following: pro-environment ${ }^{*}$ pro ecolog* ${ }^{*}$ sustain* environment ${ }^{*}$ friend ${ }^{*}$ environment good environmental positive environmental

Environmentally significant environmentally responsible

PLUS one of the following

Level 2: behavio attitud $^{*}$ act $^{*}$ habit ${ }^{*}$ practice* $^{*}$ measure* way $^{*}$ effort $^{*}$

PLUS one of the following 
Norm Activation Model Value-Belief-Norm Theory Theory of Reasoned Action Theory of Planned Behaviour Persuasion Theory Attitude-Behaviour-Context Theory Social Learning Theory

Search 2. Substitutions made include:

For environmental behaviour:

Climat* adapt ${ }^{*}$ mitigat* ${ }^{*}$ preparedness waste manag* conservation green behavior green consum* land manag* forest manag* antipollution

The terms theory or model were also substituted with:

Framework, concept*, proposition

\section{Appendix B}

Table A1. Final Papers Included in the meta-analysis.

\begin{tabular}{|c|c|c|c|}
\hline Study & Title & Issue Area & Policy \\
\hline [65] & $\begin{array}{l}\text { When do recycling attitudes predict recycling? An investigation of } \\
\text { self-reported versus observed behaviour }\end{array}$ & 1 & $\mathrm{x}$ \\
\hline [66] & What influences water conservation and towel reuse practices of hotel guests? & 3 & $\mathrm{x}$ \\
\hline [67] & $\begin{array}{l}\text { Using the Theory of Planned Behaviour to investigate the determinants of } \\
\text { recycling behaviour: a case study from Brixworth, UK }\end{array}$ & 1 & EU Landfill Directive \\
\hline [68] & $\begin{array}{l}\text { Understanding and facilitating sustainable agricultural practice: A } \\
\text { comprehensive analysis of adoption behaviour among Malaysian } \\
\text { paddy farmers }\end{array}$ & 2 & $\begin{array}{l}\text { Sustainable } \\
\text { Agricultural Practices }\end{array}$ \\
\hline [69] & $\begin{array}{l}\text { Two challenges to a moral extension of the theory of planned behaviour: moral } \\
\text { norms and just world beliefs in conservationism }\end{array}$ & 4 & $\mathrm{x}$ \\
\hline [70] & $\begin{array}{l}\text { Travellers' pro-environmental behaviours in a green lodging context: } \\
\text { Converging value-belief-norm theory and the theory of planned behaviour }\end{array}$ & 3 & Eco-friendly guidelines \\
\hline [71] & $\begin{array}{l}\text { Transcendental values and the valuation and management of } \\
\text { ecosystem services }\end{array}$ & 2 & $\mathrm{x}$ \\
\hline [72] & $\begin{array}{l}\text { Time Perspective and Sustainable Behaviour: Evidence for the Distinction } \\
\text { Between Consideration of Immediate and Future Consequences }\end{array}$ & 4 & $\mathrm{x}$ \\
\hline [73] & $\begin{array}{l}\text { Sustainable attitudes and behaviours amongst a sample of non-academic staff: } \\
\text { A case study from an Information Services Department, } \\
\text { Griffith University, Brisbane }\end{array}$ & 3 & $\begin{array}{l}\text { Institutional } \\
\text { Sustainability Initiative }\end{array}$ \\
\hline [74] & $\begin{array}{l}\text { Socio-Cognitive Determinants of Consumers' Support for the } \\
\text { Fair Trade Movement }\end{array}$ & 3 & Fair trade principles \\
\hline [75] & $\begin{array}{l}\text { Smallholder farmers' motivations for using Conservation Agriculture and the } \\
\text { roles of yield, labour and soil fertility in decision making }\end{array}$ & 2 & $\begin{array}{l}\text { Conservation } \\
\text { Agricultural Policy }\end{array}$ \\
\hline [76] & $\begin{array}{l}\text { The role of perceived socio-spatial distance in adolescents' willingness to } \\
\text { engage in pro-environmental behaviour }\end{array}$ & 4 & $\mathrm{x}$ \\
\hline [77] & $\begin{array}{l}\text { The Relative Importance of Social and Personal Norms in Explaining Intentions } \\
\text { to Choose Eco-Friendly Travel Options }\end{array}$ & 3 & $\mathrm{x}$ \\
\hline [78] & Recycling: Planned and self-expressive behaviour & 1 & $\mathrm{x}$ \\
\hline [79] & $\begin{array}{l}\text { Psychosocial and Demographic Variables Associated with Consumer Intention } \\
\text { to Purchase Sustainably Produced Foods as Defined by the } \\
\text { Midwest Food Alliance }\end{array}$ & 3 & $\mathrm{x}$ \\
\hline [80] & $\begin{array}{l}\text { A proposed structural model for housewives' recycling behaviour: A case } \\
\text { study from Turkey }\end{array}$ & 1 & Waste Management Policies \\
\hline [81] & $\begin{array}{l}\text { Pro-environmental behaviour in the workplace and the role of managers } \\
\text { and organisation }\end{array}$ & 4 & $\mathrm{x}$ \\
\hline [82] & $\begin{array}{l}\text { Predictors of Pro-Environmental Behaviours of American and Korean Students: } \\
\text { The Application of the Theory of Reasoned Action and } \\
\text { Protection Motivation Theory }\end{array}$ & 3 & $\mathrm{x}$ \\
\hline [83] & $\begin{array}{l}\text { Predictors of individuals' intention to conserve water in a lodging context: the } \\
\text { application of an extended Theory of Reasoned Action }\end{array}$ & 3 & General sustainability policies \\
\hline [84] & $\begin{array}{l}\text { Predicting residents' pro-environmental behaviours at tourist sites: The role of } \\
\text { awareness of disaster's consequences, values, and place attachment }\end{array}$ & 3 & $\mathrm{x}$ \\
\hline [85] & $\begin{array}{l}\text { Predicting pro-environmental agricultural practices: The social, psychological } \\
\text { and contextual influences on land management }\end{array}$ & 2 & $\begin{array}{l}\text { General best land } \\
\text { management practices }\end{array}$ \\
\hline
\end{tabular}


Table A1. Cont.

\begin{tabular}{|c|c|c|c|}
\hline Study & Title & Issue Area & Policy \\
\hline [86] & Predicting consumer intentions to purchase energy-efficient products & 3 & $\mathrm{x}$ \\
\hline [87] & $\begin{array}{l}\text { The norm activation model and theory-broadening: Individuals' } \\
\text { decision-making on environmentally-responsible convention attendance }\end{array}$ & 4 & $\mathrm{x}$ \\
\hline [88] & $\begin{array}{l}\text { A moral extension of the theory of planned behaviour: Norms and anticipated } \\
\text { feelings of regret in conservationism }\end{array}$ & 4 & $\mathrm{x}$ \\
\hline [89] & $\begin{array}{l}\text { Moderating effects of social value orientation on determinants of } \\
\text { Pro-environmental behaviour intention }\end{array}$ & 4 & $\mathrm{x}$ \\
\hline$[90]$ & $\begin{array}{l}\text { The Moderating Effect of Perceived Lack of Facilities on Consumers' } \\
\text { Recycling Intentions }\end{array}$ & 1 & $\begin{array}{l}\text { The Compulsory Classification } \\
\text { of Refuse program }\end{array}$ \\
\hline [91] & $\begin{array}{l}\text { Mechanism of environmental concern on intention to pay more for renewable } \\
\text { energy: Application to a developing country }\end{array}$ & 3 & Anti-pollution laws \\
\hline [92] & Linking green scepticism to green purchase behaviour & 3 & $\mathrm{x}$ \\
\hline [93] & $\begin{array}{l}\text { Investigating willingness to save energy and communication about energy use } \\
\text { in the American workplace with the attitude-behaviour-context model }\end{array}$ & 3 & $\mathrm{x}$ \\
\hline [94] & Investigating pro-Environmental Behaviours of Lithuanian University Students & 3 & $\mathrm{x}$ \\
\hline [95] & $\begin{array}{l}\text { Intention to buy eco-friendly packaged products among young consumers of } \\
\text { India: A study on developing nation }\end{array}$ & 3 & Eco-friendly Strategies \\
\hline [96] & $\begin{array}{l}\text { Influences on Student Intention and Behaviour Toward } \\
\text { Environmental Sustainability }\end{array}$ & 3 & $\mathrm{x}$ \\
\hline [97] & $\begin{array}{l}\text { Impact of fear appeals on pro-environmental behaviour and } \\
\text { crucial determinants }\end{array}$ & 4 & $\mathrm{x}$ \\
\hline [98] & $\begin{array}{l}\text { The impact of direct and indirect experiences on the development of } \\
\text { environmental knowledge, attitudes, and behaviour }\end{array}$ & 4 & $\mathrm{x}$ \\
\hline Filho [99] & $\begin{array}{l}\text { Heterogeneity in Intention to Adopt Organic Strawberry Production Practices } \\
\text { Among Producers in the Federal District, Brazil }\end{array}$ & 3 & $\mathrm{x}$ \\
\hline [100] & $\begin{array}{l}\text { Guests' pro-environmental decision-making process: Broadening the norm } \\
\text { activation framework in a lodging context }\end{array}$ & 3 & $\mathrm{x}$ \\
\hline [101] & Fostering customers' pro-environmental behaviour at a museum & 3 & $\mathrm{x}$ \\
\hline [102] & $\begin{array}{l}\text { Factors influencing green purchasing behaviour: Empirical evidence from the } \\
\text { Lebanese consumers }\end{array}$ & 3 & $\mathrm{x}$ \\
\hline [103] & $\begin{array}{l}\text { Extending the theory of planned behaviour model to explain people's energy } \\
\text { savings and carbon reduction behavioural intentions to mitigate climate } \\
\text { change in Taiwane- moral obligation matters }\end{array}$ & 3 & $\begin{array}{l}\text { The } 25 \text { G8 energy efficiency } \\
\text { recommendations }\end{array}$ \\
\hline [104] & $\begin{array}{l}\text { Extending the Theory of Planned Behaviour in the context of recycling: The } \\
\text { role of moral norms and of demographic predictors }\end{array}$ & 1 & $\mathrm{x}$ \\
\hline [105] & $\begin{array}{l}\text { An extended theory of planned behaviour model of the psychological factors } \\
\text { affecting commuters' transport mode use }\end{array}$ & 3 & $\mathrm{x}$ \\
\hline [106] & $\begin{array}{l}\text { Explaining the environmentally sustainable consumer behaviour: a social } \\
\text { capital perspective }\end{array}$ & 3 & $\mathrm{x}$ \\
\hline [107] & Explaining pro-environment consumer behaviour in air travel & 3 & $\mathrm{x}$ \\
\hline [108] & Explaining consumers' willingness to be environmentally friendly & 3 & $\mathrm{x}$ \\
\hline [109] & $\begin{array}{l}\text { Explaining consumer use of renewable energy: determinants and gender and } \\
\text { age moderator effects }\end{array}$ & 3 & $\mathrm{x}$ \\
\hline [110] & $\begin{array}{l}\text { An examination of the value-belief-norm theory model in predicting } \\
\text { pro-environmental behaviour in Taiwan }\end{array}$ & 4 & $\mathrm{x}$ \\
\hline [111] & $\begin{array}{l}\text { Environmental action and student environmental leaders: exploring the } \\
\text { influence of environmental attitudes, locus of control, and sense of } \\
\text { personal responsibility }\end{array}$ & 4 & $\mathrm{x}$ \\
\hline [112] & $\begin{array}{l}\text { Engaging Great Barrier Reef Stakeholders: Mediation Analyses of Barriers } \\
\text { Among the Antecedents of Pro-Environmental Behaviour }\end{array}$ & 4 & $\mathrm{x}$ \\
\hline [113] & $\begin{array}{l}\text { Encouraging sustainability in the workplace: a survey on the } \\
\text { pro-environmental behaviour of university employees }\end{array}$ & 4 & $\mathrm{x}$ \\
\hline [114] & $\begin{array}{l}\text { Enacting Ecological Sustainability in the MNC: A Test of an Adapted } \\
\text { Value-Belief-Norm Framework }\end{array}$ & 4 & ISO 14031 \\
\hline [115] & $\begin{array}{l}\text { Effects of values, problem awareness, and personal norm on willingness to } \\
\text { reduce personal car use }\end{array}$ & 3 & $\mathrm{x}$ \\
\hline [116] & $\begin{array}{l}\text { Effecting Durable Change: A Team Approach to Improve Environmental } \\
\text { Behaviour in the Household }\end{array}$ & 4 & Eco Team Program \\
\hline [117] & Differentiation of determinants of low-cost and high-cost recycling & 1 & $\mathrm{x}$ \\
\hline
\end{tabular}


Table A1. Cont.

\begin{tabular}{|c|c|c|c|}
\hline Study & Title & Issue Area & Policy \\
\hline [118] & $\begin{array}{l}\text { Developing an extended Theory of Planned Behaviour model to predict } \\
\text { consumers' intention to visit green hotels }\end{array}$ & 1 & $\mathrm{x}$ \\
\hline [119] & Determinants of Water Conservation Intention in Blagoevgrad, Bulgaria & 3 & $\mathrm{x}$ \\
\hline [120] & $\begin{array}{l}\text { Determinants of Southern Italian households' intention to adopt energy } \\
\text { efficiency measures in residential buildings }\end{array}$ & 3 & Energy Efficiency Policies \\
\hline [121] & $\begin{array}{l}\text { Cruise travellers' environmentally responsible decision-making: An } \\
\text { integrative framework of goal-directed behaviour and norm activation process }\end{array}$ & 3 & $\mathrm{x}$ \\
\hline [122] & $\begin{array}{l}\text { A comprehensive action determination model: Toward a broader } \\
\text { understanding of ecological behaviour using the example of travel mode choice }\end{array}$ & 3 & $\mathrm{x}$ \\
\hline [123] & $\begin{array}{l}\text { Cognitive, affective, normative, and moral triggers of sustainable intentions } \\
\text { among convention-goers }\end{array}$ & 3 & $\mathrm{x}$ \\
\hline [124] & $\begin{array}{l}\text { Behavioural intentions toward afforestation and carbon reduction by the } \\
\text { Taiwanese public }\end{array}$ & 3 & Climate change Policies \\
\hline [125] & $\begin{array}{l}\text { Attitudes, efficacy beliefs, and willingness to pay for environmental protection } \\
\text { when travelling }\end{array}$ & 3 & $x$ \\
\hline [126] & $\begin{array}{l}\text { Analysis of the ecological conservation behaviour of farmers in payment for } \\
\text { ecosystem service programs in eco-environmentally fragile areas using social } \\
\text { psychology models }\end{array}$ & 2 & $x$ \\
\hline [127] & $\begin{array}{l}\text { An analysis of intentions to recycle household waste: The roles of past } \\
\text { behaviour, perceived habit, and perceived lack of facilities }\end{array}$ & 1 & $x$ \\
\hline [128] & $\begin{array}{l}\text { Ambivalence and conservation behaviour: An exploratory study on the } \\
\text { recycling of metal cans }\end{array}$ & 1 & $x$ \\
\hline [129] & $\begin{array}{l}\text { Adolescents' Perspectives and Food Choice Behaviours in Terms of the } \\
\text { Environmental Impacts of Food Production Practices: Application of a } \\
\text { Psychosocial Model }\end{array}$ & 3 & $x$ \\
\hline [130] & $\begin{array}{l}\text { Adolescent Environmental Behaviours: Can Knowledge, Attitudes, and } \\
\text { Self-Efficacy Make a Difference? }\end{array}$ & 4 & $x$ \\
\hline [131] & $\begin{array}{l}\text { Responsibility And Environment: Ecological Norm Orientation and External } \\
\text { Factors in the Domain of Travel Mode Choice Behaviour }\end{array}$ & 3 & $x$ \\
\hline [132] & $\begin{array}{l}\text { Influences on attitude-behaviour relationships: a natural experiment with } \\
\text { curbside recycling }\end{array}$ & 1 & $x$ \\
\hline [133] & $\begin{array}{l}\text { Influence Of Socio-demographics And Environmental Attitudes on General } \\
\text { Responsible Environmental Behaviour Among Recreational Boaters }\end{array}$ & 4 & $x$ \\
\hline [134] & $\begin{array}{l}\text { Motivations to Participate in Riparian Improvement Programs: Applying the } \\
\text { Theory of Planned Behaviour }\end{array}$ & 2 & $x$ \\
\hline [135] & $\begin{array}{l}\text { Promoting Sustainable Consumption: Determinants of Green Purchases by } \\
\text { Swiss Consumers }\end{array}$ & 3 & $x$ \\
\hline [136] & $\begin{array}{l}\text { Measuring Responsible Environmental Behaviour: Self-Reported and } \\
\text { Other-Reported Measures and Their Differences in Testing a Behavioural Model }\end{array}$ & 4 & $x$ \\
\hline [137] & $\begin{array}{l}\text { Measuring implementation intentions in the context of the theory of } \\
\text { planned behaviour }\end{array}$ & 1 & $x$ \\
\hline [138] & $\begin{array}{l}\text { Understanding air force members' intentions to participate in } \\
\text { pro-environmental behaviours: an application of the theory of } \\
\text { planned behaviour }\end{array}$ & 4 & $x$ \\
\hline [139] & $\begin{array}{l}\text { The Proposition of a General Version of the Theory of Planned Behaviour: } \\
\text { Predicting Ecological Behaviour }\end{array}$ & 4 & $x$ \\
\hline [140] & $\begin{array}{l}\text { Predicting antipollution behaviour: The role of molar behavioural intentions, } \\
\text { past behaviour and locus of control }\end{array}$ & 4 & $x$ \\
\hline [141] & The Impact of Norms And Assumed Consequences On Recycling Behaviour & 1 & $\mathrm{x}$ \\
\hline [142] & Beyond the intention-behaviour mythology An integrated model of recycling & 1 & $\mathrm{x}$ \\
\hline [143] & $\begin{array}{l}\text { Understanding the Relationship Between Christian Orthodoxy and } \\
\text { Environmentalism: The Mediating Role of Perceived } \\
\text { Environmental Consequences }\end{array}$ & 4 & $\mathrm{x}$ \\
\hline [144] & $\begin{array}{l}\text { Integrating social value orientation and the consideration of future } \\
\text { consequences within the extended norm activation model of } \\
\text { pro-environmental behaviour }\end{array}$ & 4 & $\mathrm{x}$ \\
\hline [145] & Responsibility As A Predictor of Ecological Behaviour & 4 & $\mathrm{x}$ \\
\hline [146] & Environmental Attitude and ecological Behaviour & 4 & $\mathrm{x}$ \\
\hline [147] & $\begin{array}{l}\text { The Effects of Environmental Concern on Environmentally Friendly Consumer } \\
\text { Behaviour: An Exploratory Study }\end{array}$ & 3 & $\mathrm{x}$ \\
\hline [148] & Travel behaviour and environmental concern & 3 & $x$ \\
\hline
\end{tabular}


Table A1. Cont.

\begin{tabular}{|c|c|c|c|}
\hline Study & Title & Issue Area & Policy \\
\hline [149] & Constraints On Environmental Behaviour & 4 & $\mathrm{x}$ \\
\hline [150] & The theory of planned behaviour: Self-identity, social identity and group norms & 4 & $\mathrm{x}$ \\
\hline [151] & $\begin{array}{l}\text { Action speaks louder than words: The effect of personal attitudes and family } \\
\text { norms on adolescents' pro-environmental behaviour }\end{array}$ & 4 & $\mathrm{x}$ \\
\hline [152] & $\begin{array}{l}\text { What matters to promote consumers' intention to patronize sustainable } \\
\text { business-and-industry (B\&I) food services? }\end{array}$ & 3 & $\mathrm{x}$ \\
\hline [153] & $\begin{array}{l}\text { Motivating energy conservation in the workplace: An evaluation of the use of } \\
\text { group-level feedback and peer education }\end{array}$ & 3 & $\mathrm{x}$ \\
\hline [154] & $\begin{array}{l}\text { Environmentally friendly behaviour and green purchase in } \\
\text { Austria and Lithuania }\end{array}$ & 3 & $\mathrm{x}$ \\
\hline [2] & $\begin{array}{l}\text { Sustainable transportation in Argentina: Values, beliefs, norms and } \\
\text { car use reduction }\end{array}$ & 3 & Transport pricing policies \\
\hline [155] & $\begin{array}{l}\text { A study of goal frames shaping pro-environmental behaviour in } \\
\text { university students }\end{array}$ & 4 & $\mathrm{x}$ \\
\hline [156] & The role of Islamic values on green purchase intention & 3 & $\mathrm{x}$ \\
\hline [157] & $\begin{array}{l}\text { Physical Outdoor Activity versus Indoor Activity: Their Influence on } \\
\text { Environmental Behaviours }\end{array}$ & 4 & $\mathrm{x}$ \\
\hline [158] & A Mediation Model of Air Travellers' Voluntary Climate Action & 3 & $\mathrm{x}$ \\
\hline [159] & $\begin{array}{l}\text { Is the intention to travel in a pro-environmental manner and the intention to } \\
\text { use the car determined by different factors? }\end{array}$ & 3 & $\mathrm{x}$ \\
\hline [160] & $\begin{array}{l}\text { Exploring people's willingness to bike using a combination of the theory of } \\
\text { planned behavioural and the trans-theoretical model }\end{array}$ & 3 & $\mathrm{x}$ \\
\hline [161] & $\begin{array}{l}\text { Exploring Additional Determinants of Environmentally Responsible Behaviour: } \\
\text { The Influence of Environmental Literature and Environmental Attitudes }\end{array}$ & 4 & $\mathrm{x}$ \\
\hline [162] & $\begin{array}{l}\text { Assessing the intention-behaviour gap in electronic waste recycling: } \\
\text { the case of Brazil }\end{array}$ & 1 & $\mathrm{x}$ \\
\hline [163] & $\begin{array}{l}\text { Acceptability of travel demand management measures: The importance of } \\
\text { problem awareness, personal norm, freedom, and fairness }\end{array}$ & 3 & $\mathrm{x}$ \\
\hline [164] & $\begin{array}{l}\text { Environmental locus of control, sympathy, and pro-environmental behaviour: } \\
\text { A Test of Geller's Actively Caring Hypothesis }\end{array}$ & 4 & $\mathrm{x}$ \\
\hline [165] & $\begin{array}{l}\text { Repeated Behaviour and Environmental Psychology: The Role of Personal } \\
\text { Involvement and Habit Formation in Explaining Water Consumption }\end{array}$ & 3 & $\mathrm{x}$ \\
\hline [166] & $\begin{array}{l}\text { Conservation technology adoption decisions and the theory of } \\
\text { planned behaviour }\end{array}$ & 2 & $\begin{array}{l}\text { Water saving irrigation } \\
\text { technology }\end{array}$ \\
\hline [167] & Motivations and behaviours that support recycling & 1 & $\mathrm{x}$ \\
\hline [168] & Effects of increased awareness on choice of travel mode & 3 & $\mathrm{x}$ \\
\hline [169] & $\begin{array}{l}\text { Social context, personal norms and the use of public transportation: } \\
\text { Two field studies }\end{array}$ & 3 & $\mathrm{x}$ \\
\hline [170] & Accounting for Sustained Volunteering by Young People: An Expanded TPB & 4 & $\mathrm{x}$ \\
\hline [171] & $\begin{array}{l}\text { The Dynamic Interaction of Personal Norms and Environment-Friendly } \\
\text { Buying Behaviour: A Panel Study }\end{array}$ & 3 & $\mathrm{x}$ \\
\hline
\end{tabular}

Note: 1 = recycling; 2 = land management; 3 = sustainable consumer behaviour; 4 = general ecological behaviour; $\mathrm{X}$ $=$ No policy highlighted. 


\section{Appendix C}

Table A2. A 95\%-confidence interval of the correlations calculated under the random effect assumptions (model).

\begin{tabular}{|c|c|c|c|c|c|c|c|c|c|c|c|c|c|c|c|c|c|c|c|c|}
\hline SN & Construct & & 1 & 2 & 3 & 4 & 5 & 6 & 7 & 8 & 9 & 10 & 11 & 12 & 13 & 14 & 15 & 16 & 17 & 18 \\
\hline 1 & knowledge & - & - & & & & & & & & & & & & & & & & & \\
\hline 2 & beliefs & $\begin{array}{l}\text { LCI 95\% } \\
\text { UCI 95\% }\end{array}$ & $\begin{array}{l}0.21 \\
0.73\end{array}$ & - & & & & & & & & & & & & & & & & \\
\hline 3 & Awareness or consciousness & $\begin{array}{l}\text { LCI 95\% } \\
\text { UCI 95\% }\end{array}$ & $\begin{array}{l}0.03 \text { NS } \\
0.49\end{array}$ & $\begin{array}{l}-0.15 \text { NS } \\
0.45\end{array}$ & - & & & & & & & & & & & & & & & \\
\hline 4 & Attitude & $\begin{array}{l}\text { LCI 95\% } \\
\text { UCI 95\% }\end{array}$ & $\begin{array}{l}0.04 \\
0.61\end{array}$ & $\begin{array}{l}0.34 \\
0.66\end{array}$ & $\begin{array}{l}0.17 \\
0.44\end{array}$ & - & & & & & & & & & & & & & & \\
\hline 5 & Habit & $\begin{array}{l}\text { LCI 95\% } \\
\text { UCI 95\% }\end{array}$ & $\begin{array}{l}0.12^{\mathrm{a}} \\
0.32\end{array}$ & & $\begin{array}{l}-0.09^{\mathrm{a}} \\
0.13\end{array}$ & $\begin{array}{l}-0.24 \mathrm{NS} \\
0.30\end{array}$ & - & & & & & & & & & & & & & \\
\hline 6 & Intention & $\begin{array}{l}\text { LCI 95\% } \\
\text { UCI 95\% }\end{array}$ & $\begin{array}{l}0.06 \\
0.66\end{array}$ & $\begin{array}{l}0.05 \\
0.69\end{array}$ & $\begin{array}{l}0.28 \\
0.53\end{array}$ & $\begin{array}{l}0.43 \\
0.61\end{array}$ & $\begin{array}{l}-0.37 \text { NS } \\
0.55\end{array}$ & - & & & & & & & & & & & & \\
\hline 7 & Behavioural willingness & $\begin{array}{l}\text { LCI 95\% } \\
\text { UCI 95\% }\end{array}$ & $\begin{array}{l}0.15 \\
0.38 \\
\end{array}$ & $\begin{array}{l}0.18^{\mathrm{a}} \\
0.28\end{array}$ & $\begin{array}{l}0.29 \\
0.48\end{array}$ & $\begin{array}{l}0.00 \\
0.38\end{array}$ & 0 & $\begin{array}{l}0.08 \\
0.68\end{array}$ & - & & & & & & & & & & & \\
\hline 8 & Behaviour & $\begin{array}{l}\text { LCI 95\% } \\
\text { UCI 95\% }\end{array}$ & $\begin{array}{l}0.17 \\
0.39\end{array}$ & $\begin{array}{l}0.17 \\
0.30 \\
\end{array}$ & $\begin{array}{l}0.13 \\
0.31 \\
\end{array}$ & $\begin{array}{l}0.27 \\
0.46\end{array}$ & $\begin{array}{l}0.09 \\
0.45\end{array}$ & $\begin{array}{l}0.35 \\
0.52 \\
\end{array}$ & $0.19-0.48$ & - & & & & & & & & & & \\
\hline 9 & Social norm & $\begin{array}{l}\text { LCI 95\% } \\
\text { UCI 95\% }\end{array}$ & $\begin{array}{l}0.04 \\
0.39\end{array}$ & & $\begin{array}{l}-0.03 \\
0.56\end{array}$ & $\begin{array}{l}0.27 \\
0.46\end{array}$ & & $\begin{array}{l}0.34 \\
0.50 \\
\end{array}$ & & $\begin{array}{l}0.31 \\
0.51\end{array}$ & - & & & & & & & & & \\
\hline 10 & Moral norm & $\begin{array}{l}\text { LCI 95\% } \\
\text { UCI 95\% }\end{array}$ & $\begin{array}{l}0.13 \\
0.32\end{array}$ & & $\begin{array}{l}0.32 \\
0.50\end{array}$ & $\begin{array}{l}0.36 \\
0.79\end{array}$ & & $\begin{array}{l}-0.22 \\
0.68\end{array}$ & & $\begin{array}{l}0.15 \\
0.54\end{array}$ & & - & & & & & & & & \\
\hline 11 & Subjective norm & $\begin{array}{l}\text { LCI 95\% } \\
\text { UCI 95\% } \\
\end{array}$ & $\begin{array}{l}0.01 \\
0.86 \\
\end{array}$ & & $0.27-0.51$ & $0.38-0.52$ & & $0.37-0.48$ & & $0.14-0.35$ & & & - & & & & & & & \\
\hline 12 & Emotions & $\begin{array}{l}\text { LCI 95\% } \\
\text { UCI 95\% }\end{array}$ & $\begin{array}{l}0.35^{\mathrm{a}} \\
0.53 \\
\end{array}$ & & $\begin{array}{l}0.06 \\
0.40\end{array}$ & $\begin{array}{l}-0.05 \text { NS } \\
0.56\end{array}$ & & $\begin{array}{l}0.13 \\
0.58\end{array}$ & & & $\begin{array}{l}-024 \mathrm{NS} \\
0.43\end{array}$ & $\begin{array}{l}-0.39 \mathrm{NS} \\
0.65\end{array}$ & $\begin{array}{l}0.16 \\
0.44\end{array}$ & - & & & & & & \\
\hline 13 & Self-efficacy & $\begin{array}{l}\text { LCI 95\% } \\
\text { UCI 95\% }\end{array}$ & $\begin{array}{l}0.03 \\
0.32\end{array}$ & & $\begin{array}{l}0.17 \\
0.46\end{array}$ & $\begin{array}{l}0.32 \\
0.46\end{array}$ & $\begin{array}{l}0.12 \\
0.43\end{array}$ & $\begin{array}{l}0.40 \\
0.57\end{array}$ & $\begin{array}{l}0.27 \\
0.50\end{array}$ & $\begin{array}{l}0.19 \\
0.35\end{array}$ & $\begin{array}{l}0.17 \\
0.43\end{array}$ & $\begin{array}{l}0.24 \\
0.65\end{array}$ & $\begin{array}{l}0.46 \\
0.51\end{array}$ & & - & & & & & \\
\hline 14 & Perceived consequences & $\begin{array}{l}\text { LCI 95\% } \\
\text { UCI 95\% } \\
\end{array}$ & $\begin{array}{l}0.05 \\
0.38 \\
\end{array}$ & & $\begin{array}{l}0.47 \\
0.81 \\
\end{array}$ & $\begin{array}{l}0.27 \\
0.55 \\
\end{array}$ & & $\begin{array}{l}0.25 \\
0.51\end{array}$ & & $\begin{array}{l}0.09 \\
0.22\end{array}$ & $\begin{array}{l}0.12 \\
0.23 \\
\end{array}$ & $\begin{array}{l}0.38 \\
0.58\end{array}$ & & & & - & & & & \\
\hline 15 & Ascription of responsibility & $\begin{array}{l}\text { LCI 95\% } \\
\text { UCI 95\% } \\
\end{array}$ & & & $\begin{array}{l}0.19 \\
0.58 \\
\end{array}$ & $\begin{array}{l}0.14 \\
0.56 \\
\end{array}$ & & $\begin{array}{l}0.42 \\
0.60\end{array}$ & & $\begin{array}{l}0.15 \\
0.31 \\
\end{array}$ & $\begin{array}{l}0.16 \\
0.52 \\
\end{array}$ & & $\begin{array}{l}0.38 \\
0.56\end{array}$ & & & & - & & & \\
\hline 16 & Situational factors & $\begin{array}{l}\text { LCI 95\% } \\
\text { UCI 95\% }\end{array}$ & & & & & & $\begin{array}{l}-0.19 \mathrm{NS} \\
0.15\end{array}$ & & $\begin{array}{l}-0.18 \mathrm{NS} \\
0.05\end{array}$ & & & & & & & & - & & \\
\hline 17 & Environmental value & $\begin{array}{l}\text { LCI 95\% } \\
\text { UCI 95\% }\end{array}$ & $\begin{array}{l}0.31 \\
0.49\end{array}$ & & & $\begin{array}{l}0.18 \\
0.60\end{array}$ & & $\begin{array}{l}0.26 \\
0.51\end{array}$ & & & & & & & & & & & - & \\
\hline 18 & Environmental concern & $\begin{array}{l}\text { LCI 95\% } \\
\text { UCI 95\% }\end{array}$ & $\begin{array}{l}0.15 \\
0.44\end{array}$ & & & $\begin{array}{l}0.16 \\
0.33\end{array}$ & & $\begin{array}{l}0.23 \\
0.37\end{array}$ & & & & & & & & & & & & - \\
\hline
\end{tabular}

Note: $\mathrm{a}=$ no pooled correlation (i.e., only one correlation was used but we calculated the $95 \% \mathrm{CI}$ ), $\mathrm{NS}=$ non-significant relationship (all other $\mathrm{r}$ values are significant at the $\mathrm{p} \leq 0.05$ ); $\mathrm{LCI}=$

Lower Confidence interval; UCI = upper Confidence interval. 


\section{Appendix D}

Table A3. Results of test of heterogeneity.

\begin{tabular}{|c|c|c|c|c|c|c|c|c|c|c|c|c|c|c|c|c|c|c|c|}
\hline SN & VARIABLE & 1 & 2 & 3 & 4 & 5 & 6 & 7 & 8 & 9 & 10 & 11 & 12 & 13 & 14 & 15 & 16 & 17 & 18 \\
\hline 1 & knowledge & - & & & & & & & & & & & & & & & & & \\
\hline 2 & beliefs & $\begin{array}{l}\mathrm{Q}(158.23) \\
\mathrm{df}(3) \\
\mathrm{P}(0.00) \\
\mathrm{I}(98.10)\end{array}$ & - & & & & & & & & & & & & & & & & \\
\hline 3 & $\begin{array}{l}\text { Awareness or } \\
\text { consciousness }\end{array}$ & $\begin{array}{l}\text { Q(10.41) } \\
\text { Df(1) } \\
\mathrm{P}(0.00) \\
\mathrm{I}(90.39)\end{array}$ & $\begin{array}{l}\mathrm{Q}(93.29) \\
\mathrm{Df}(2) \\
\mathrm{P}(0.00) \\
\mathrm{I}(97.86)\end{array}$ & - & & & & & & & & & & & & & & & \\
\hline 4 & Attitude & $\begin{array}{l}\mathrm{Q}(1218.16) \\
\mathrm{Df}(9) \\
\mathrm{P}(0.00) \\
\mathrm{I}(99.26)\end{array}$ & $\begin{array}{l}\text { Q(264.47) } \\
\text { Df(6) } \\
\text { P( (0.00) } \\
\text { I(97.73) }\end{array}$ & $\begin{array}{l}\mathrm{Q}(155.59) \\
\mathrm{Df}(9) \\
\mathrm{P}(0.00) \\
\mathrm{I}(94.22)\end{array}$ & - & & & & & & & & & & & & & & \\
\hline 5 & Habit & $\begin{array}{l}\mathrm{Q}(0.00) \\
\mathrm{Df}(0) \\
\mathrm{P}(1.00) \\
\mathrm{I}(0.00) \text { ns }\end{array}$ & & $\begin{array}{l}\mathrm{Q}(0.00) \\
\mathrm{Df}(0) \\
\mathrm{P}(1.00) \\
\mathrm{I}(0.00) \mathrm{ns}\end{array}$ & $\begin{array}{l}\mathrm{Q}(80.56) \\
\mathrm{Df}(3) \\
\mathrm{P}(0.00) \\
\mathrm{I}(96.28)\end{array}$ & - & & & & & & & & & & & & & \\
\hline 6 & Intention & $\begin{array}{l}\text { Q(915.77) } \\
\text { Df(7) } \\
\mathrm{P}(0.00) \\
\mathrm{I}(99.24)\end{array}$ & $\begin{array}{l}\mathrm{Q}(231.94) \\
\mathrm{Df}(3) \\
\mathrm{P}(0.00) \\
\mathrm{I}(98.71)\end{array}$ & $\begin{array}{l}\text { Q(327.09) } \\
\text { Df(12) } \\
\text { P(0.00) } \\
I(96.33)\end{array}$ & $\begin{array}{l}\mathrm{Q}(3460.70) \\
\mathrm{Df}(45) \\
\mathrm{P}(0.00) \\
\mathrm{I}(98.70)\end{array}$ & $\begin{array}{l}\text { Q(328.51) } \\
\text { Df(4) } \\
\text { P( }(0.00) \\
\text { I( } 98.78)\end{array}$ & - & & & & & & & & & & & & \\
\hline 7 & Behavioural willingness & $\begin{array}{l}\text { Q(18.96) } \\
\text { Df(4) } \\
P(0.00) \\
I(78.90)\end{array}$ & $\begin{array}{l}\mathrm{Q}(0.00) \\
\mathrm{Df}(0) \\
\mathrm{P}(1.00) \\
\mathrm{I}(0.00) \mathrm{ns}\end{array}$ & $\begin{array}{l}\mathrm{Q}(35.28) \\
\mathrm{Df}(5) \\
\mathrm{P}(0.00) \\
\mathrm{I}(85.83)\end{array}$ & $\begin{array}{l}\mathrm{Q}(32.72) \\
\mathrm{Df}(3) \\
\mathrm{P}(0.00) \\
\mathrm{I}(90.83)\end{array}$ & 0 & $\begin{array}{l}\mathrm{Q}(99.81) \\
\mathrm{Df}(3) \\
\mathrm{P}(0.00) \\
\mathrm{I}(96.99)\end{array}$ & - & & & & & & & & & & & \\
\hline 8 & Behaviour & $\begin{array}{l}\text { Q(106.74) } \\
\text { Df(8) } \\
\mathrm{P}(0.00) \\
\mathrm{I}(92.50)\end{array}$ & $\begin{array}{l}\mathrm{Q}(49.43) \\
\mathrm{Df}(6) \\
\mathrm{P}(0.00) \\
\mathrm{I}(87.86)\end{array}$ & $\begin{array}{l}\text { Q(273.26) } \\
\text { Df(17) } \\
\text { P(0.00) } \\
\mathrm{I}(93.78)\end{array}$ & $\begin{array}{l}\mathrm{Q}(1350.24) \\
\mathrm{Df}(29) \\
\mathrm{P}(0.00) \\
\mathrm{I}(97.85)\end{array}$ & $\begin{array}{l}\mathrm{Q}(36.33) \\
\mathrm{Df}(3) \\
\mathrm{P}(0.00) \\
\mathrm{I}(91.74)\end{array}$ & $\begin{array}{l}\mathrm{Q}(842.73) \\
\mathrm{Df}(28) \\
\mathrm{P}(0.00) \\
\mathrm{I}(98.68)\end{array}$ & $\begin{array}{l}\mathrm{Q}(39.26) \\
\mathrm{Df}(4) \\
\mathrm{P}(0.00) \\
\mathrm{I}(89.81)\end{array}$ & - & & & & & & & & & & \\
\hline 9 & Social norm & $\begin{array}{l}\text { Q(4.91) } \\
\text { Df(1) } \\
P(0.03) \\
I(79.65)\end{array}$ & & $\begin{array}{l}\mathrm{Q}(20.90) \\
\mathrm{Df}(1) \\
\mathrm{P}(0.00) \\
\mathrm{I}(95.22)\end{array}$ & $\begin{array}{l}\text { Q(65.54) } \\
\mathrm{Df}(5) \\
\mathrm{P}(0.00) \\
\mathrm{I}(92.37)\end{array}$ & & $\begin{array}{l}\text { Q(108.01) } \\
\text { Df(8) } \\
\text { P(0.00) } \\
I(92.59)\end{array}$ & & $\begin{array}{l}\mathrm{Q}(82.66) \\
\mathrm{DF}(8) \\
\mathrm{P}(0.00) \\
\mathrm{I}(90.32)\end{array}$ & - & & & & & & & & & \\
\hline 10 & Moral norm & $\begin{array}{l}\mathrm{Q}(6.31) \\
\mathrm{Df}(2) \\
\mathrm{P}(0.04) \\
\mathrm{I}(68.30)\end{array}$ & & $\begin{array}{l}\mathrm{Q}(281.63) \\
\mathrm{Df}(13) \\
\mathrm{P}(0.00) \\
\mathrm{I}(95.38)\end{array}$ & $\begin{array}{l}\mathrm{Q}(4785.79) \\
\mathrm{Df}(17) \\
\mathrm{P}(0.00) \\
\mathrm{I}(99.64)\end{array}$ & & $\begin{array}{l}\mathrm{Q}(1505.70) \\
\mathrm{Df}(12) \\
\mathrm{P}(0.00) \\
\mathrm{I}(99.20)\end{array}$ & & $\begin{array}{l}\mathrm{Q}(2185.43) \\
\mathrm{DF}(18) \\
\mathrm{P}(0.00) \\
\mathrm{I}(99.18)\end{array}$ & & - & & & & & & & & \\
\hline 11 & Subjective norm & $\begin{array}{l}\mathrm{Q}(77.03) \\
\mathrm{Df}(1) \\
\mathrm{P}(0.00) \\
\mathrm{I}(98.70)\end{array}$ & & $\begin{array}{l}\mathrm{Q}(47.32) \\
\mathrm{Df}(5) \\
\mathrm{P}(0.00) \\
\mathrm{I}(89.43)\end{array}$ & $\begin{array}{l}\mathrm{Q}(1563.64) \\
\mathrm{Df}(41) \\
\mathrm{P}(0.00) \\
\mathrm{I}(97.38)\end{array}$ & & $\begin{array}{l}\mathrm{Q}(596.75) \\
\mathrm{Df}(32) \\
\mathrm{P}(0.00) \\
\mathrm{I}(94.64)\end{array}$ & & $\begin{array}{l}\mathrm{Q}(513.02) \\
\mathrm{DF}(19) \\
\mathrm{P}(0.00) \\
\mathrm{I}(96.30)\end{array}$ & & & - & & & & & & & \\
\hline
\end{tabular}


Table A3. Cont.

\begin{tabular}{|c|c|c|c|c|c|c|c|c|c|c|c|c|c|c|c|c|c|c|c|}
\hline SN & VARIABLE & 1 & 2 & 3 & 4 & 5 & 6 & 7 & 8 & 9 & 10 & 11 & 12 & 13 & 14 & 15 & 16 & 17 & 18 \\
\hline 12 & Emotions e.g., guilt & $\begin{array}{l}\mathrm{Q}(0.00) \\
\mathrm{Df}(0) \\
\mathrm{P}(1.00) \\
\mathrm{I}(0.00) \text { ns }\end{array}$ & & $\begin{array}{l}\mathrm{Q}(289.17) \\
\mathrm{DF}(9) \\
\mathrm{P}(0.00) \\
\mathrm{I}(96.89)\end{array}$ & $\begin{array}{l}\mathrm{Q}(345.39) \\
\mathrm{Df}(5) \\
\mathrm{P}(0.00) \\
\mathrm{I}(98.55)\end{array}$ & & $\begin{array}{l}\mathrm{Q}(1106.91) \\
\mathrm{Df}(12) \\
\mathrm{P}(0.00) \\
\mathrm{I}(98.92)\end{array}$ & & $\begin{array}{l}\text { Q(230.76) } \\
D F(4) \\
P(0.00) \\
I(98.27)\end{array}$ & & & & - & & & & & & \\
\hline 13 & Self-efficacy & $\begin{array}{l}\mathrm{Q}(42.99) \\
\operatorname{Df}(3) \\
\mathrm{P}(0.00) \\
\mathrm{I}(93.02) \\
\end{array}$ & & $\begin{array}{l}\mathrm{Q}(69.99) \\
\mathrm{DF}(5) \\
\mathrm{P}(0.00) \\
\mathrm{I}(92.86)\end{array}$ & $\begin{array}{l}\mathrm{Q}(1304.70) \\
\mathrm{Df}(36) \\
\mathrm{P}(0.00) \\
\mathrm{I}(97.24)\end{array}$ & $\begin{array}{l}\mathrm{Q}(5.73) \\
\mathrm{Df}(1) \\
\mathrm{P}(0.02) \\
\mathrm{I}(82.55)\end{array}$ & $\begin{array}{l}\mathrm{Q}(2218.73) \\
\operatorname{Df}(38) \\
\mathrm{P}(0.00) \\
\mathrm{I}(98.29)\end{array}$ & $\begin{array}{l}\mathrm{Q}(39.95) \\
\mathrm{Df}(5) \\
\mathrm{P}(0.00) \\
\mathrm{I}(87.48)\end{array}$ & $\begin{array}{l}\mathrm{Q}(409.37) \\
\mathrm{DF}(22) \\
\mathrm{P}(0.00) \\
\mathrm{I}(94.63)\end{array}$ & $\begin{array}{l}\mathrm{Q}(22.87) \\
\mathrm{DF}(3) \\
\mathrm{P}(0.00) \\
\mathrm{I}(86.88)\end{array}$ & $\begin{array}{l}\mathrm{Q}(202.82) \\
\mathrm{DF}(4) \\
\mathrm{P}(0.00) \\
\mathrm{I}(98.03)\end{array}$ & $\begin{array}{l}\mathrm{Q}(325.26) \\
\mathrm{DF}(8) \\
\mathrm{P}(0.00) \\
\mathrm{I}(97.54)\end{array}$ & & - & & & & & \\
\hline 14 & Perceived consequences & $\begin{array}{l}\mathrm{Q}(15.21) \\
\mathrm{Df}(2) \\
\mathrm{P}(0.00) \\
\mathrm{I}(86.85) \\
\end{array}$ & & $\begin{array}{l}\mathrm{Q}(233.26) \\
\mathrm{Df}(5) \\
\mathrm{P}(0.00) \\
\mathrm{I}(97.86)\end{array}$ & $\begin{array}{l}\mathrm{Q}(214.84) \\
\mathrm{Df}(9) \\
\mathrm{P}(0.00) \\
\mathrm{I}(95.81) \\
\end{array}$ & & $\begin{array}{l}\mathrm{Q}(670.23) \\
\mathrm{Df}(18) \\
\mathrm{P}(0.00) \\
\mathrm{I}(97.31)\end{array}$ & & $\begin{array}{l}\mathrm{Q}(51.40) \\
\operatorname{Df}(11) \\
\mathrm{P}(0.00) \\
\mathrm{I}(78.60) \\
\end{array}$ & $\begin{array}{l}\mathrm{Q}(1.07) \\
\mathrm{DF}(2) \\
\mathrm{P}(0.59) \\
\mathrm{I}(0.00)\end{array}$ & $\begin{array}{l}\text { Q(315.72) } \\
\text { DF(11) } \\
P(0.00) \\
I(96.52) \\
\end{array}$ & & & & - & & & & \\
\hline 15 & $\begin{array}{l}\text { Ascription of } \\
\text { responsibility }\end{array}$ & & & $\begin{array}{l}\mathrm{Q}(14.16) \\
\mathrm{Df}(2) \\
\mathrm{P}(0.00) \\
\mathrm{I}(85.88)\end{array}$ & $\begin{array}{l}\mathrm{Q}(82.92) \\
\mathrm{Df}(4) \\
\mathrm{P}(0.00) \\
\mathrm{I}(95.18)\end{array}$ & & $\begin{array}{l}\mathrm{Q}(70.85) \\
\operatorname{Df}(7) \\
\mathrm{P}(0.00) \\
\mathrm{I}(90.12) \\
\end{array}$ & & $\begin{array}{l}\mathrm{Q}(15.87) \\
\mathrm{Df}(5) \\
\mathrm{P}(0.01) \\
\mathrm{I}(68.50)\end{array}$ & $\begin{array}{l}\mathrm{Q}(7.49) \\
\mathrm{DF}(1) \\
\mathrm{P}(0.01) \\
\mathrm{I}(86.65)\end{array}$ & & $\begin{array}{l}\mathrm{Q}(6.95) \\
\mathrm{DF}(2) \\
\mathrm{P}(0.03) \\
\mathrm{I}(71.22)\end{array}$ & & & & - & & & \\
\hline 16 & Situational factors & & & & & & $\begin{array}{l}\mathrm{Q}(185.50) \\
\mathrm{Df}(8) \\
\mathrm{P}(0.00) \\
\mathrm{I}(95.68)\end{array}$ & & $\begin{array}{l}\mathrm{Q}(159.18) \\
\mathrm{DF}(10) \\
\mathrm{P}(0.00) \\
\mathrm{I}(93.72) \\
\end{array}$ & & & & & & & & - & & \\
\hline 17 & Environmental value & $\begin{array}{l}Q(2.36) \\
\text { Df(1) } \\
P(0.12) \\
I(57.66) n s\end{array}$ & & & $\begin{array}{l}Q(10.16) \\
D F(1) \\
P(0.00) \\
I(90.1) 6 \\
\end{array}$ & & $\begin{array}{l}\text { Q(78.41) } \\
\operatorname{Df(6)} \\
I(0.00) \\
I(92.35) \\
\end{array}$ & & & & & & & & & & & - & \\
\hline 18 & Environmental concern & $\begin{array}{l}\mathrm{Q}(22.14) \\
\mathrm{Df}(3) \\
\mathrm{P}(0.00) \\
\mathrm{I}(86.45)\end{array}$ & & & $\begin{array}{l}\mathrm{Q}(30.64) \\
\mathrm{Df}(6) \\
\mathrm{P}(0.00) \\
\mathrm{I}(80.42)\end{array}$ & & $\begin{array}{l}\mathrm{Q}(59.53) \\
\mathrm{Df}(10) \\
\mathrm{P}(0.00) \\
\mathrm{I}(82.20)\end{array}$ & & & & & & & & & & & & - \\
\hline
\end{tabular}




\section{References}

1. Chen, C.-F.; Xu, X.; Frey, S. Who wants solar water heaters and alternative fuel vehicles? Assessing social-psychological predictors of adoption intention and policy support in China. Energy Res. Soc. Sci. 2016, 15, 1-11. [CrossRef]

2. Jakovcevic, A.; Steg, L. Sustainable transportation in Argentina: Values, beliefs, norms and car use reduction. Transp. Res. Part F Traffic Psychol. Behav. 2013, 20, 70-79. [CrossRef]

3. Kesternich, M.; Reif, C.; Rübbelke, D. Recent Trends in Behavioral Environmental Economics. Environ. Resour. Econ. 2017, 67, 403-411. [CrossRef]

4. Blackstock, K.; Ingram, J.; Burton, R.; Brown, K.; Slee, B. Understanding and influencing behaviour change by farmers to improve water quality. Sci. Total. Environ. 2010, 408, 5631-5638. [CrossRef]

5. Prager, K. Understanding Behaviour Change: How to Apply Theories of Behaviour Change to Seweb and Related Public Engagement Activities; Scottish Government/Scottish Environment Protection Agency (SEPA): Aberdeen, UK; Edinburg, TX, USA, 2012.

6. Vrain, E.; Lovett, A. The roles of farm advisors in the uptake of measures for the mitigation of diffuse water pollution. Land Use Policy 2016, 54, 413-422. [CrossRef]

7. Vrain, E.; Lovett, A.A.; Noble, L.; Grant, F. Farmer Attitudes towards Diffuse Pollution Mitigation Measures in England; Department for Environment, Food \& Rural Affairs: London, UK, 2014.

8. Lockie, S.; Higgins, V. Roll-out neoliberalism and hybrid practices of regulation in Australian agri-environmental governance. J. Rural. Stud. 2007, 23, 1-11. [CrossRef]

9. Dwyer, J.; Mills, J.; Ingram, J.; Taylor, J.; Burton, R. Understanding and Influencing Positive Behaviour Change in Farmers and Land Managers; CCRI: Warwick, RI, USA; Macaulay Institute: Aberdeen, UK, 2007.

10. Environment Agency. Catchment Sensitive Farming-ECSFDI Phase 1 \& 2 Evaluation Report; Environment Agency Bristol: Bristol, UK, 2011.

11. Environment Agency. Catchment Sensitive Farming: A Clear Solution for Farmers; Environment Agency: Bristol, UK, 2014.

12. DPMAG. Strategy to Reduce Diffuse Pollution; Scottish Environment Protection Agency: Edinburgh, UK, 2015.

13. Okumah, M.; Martin-Ortega, J.; Novo, P. Effects of awareness on farmers' compliance with diffuse pollution mitigation measures: A conditional process modelling. Land Use Policy 2018, 76, 36-45. [CrossRef]

14. Okumah, M.; Chapman, P.; Martin-Ortega, J.; Novo, P. Mitigating Agricultural Diffuse Pollution: Uncovering the Evidence Base of the Awareness-Behaviour-Water Quality Pathway. Water 2019, 11, 29. [CrossRef]

15. Okumah, M.; Yeboah, A.S.; Nkiaka, E.; Azerigyik, R.A. What Determines Behaviours towards Water Resources Management in a Rural Context? Results of a Quantitative Study. Resources 2019, 8, 109. [CrossRef]

16. Baumgart-Getz, A.; Prokopy, L.S.; Floress, K. Why farmers adopt best management practice in the United States: A meta-analysis of the adoption literature. J. Environ. Manag. 2012, 96, 17-25. [CrossRef]

17. MacGregor, C.; Warren, C.R. Adopting sustainable farm management practices within a Nitrate Vulnerable Zone in Scotland: The view from the farm. Agric. Ecosyst. Environ. 2006, 113, 108-119. [CrossRef]

18. Barnes, A.; Willock, J.; Hall, C.; Toma, L. Farmer perspectives and practices regarding water pollution control programmes in Scotland. Agric. Water Manag. 2009, 96, 1715-1722. [CrossRef]

19. Inman, A.; Winter, M.; Wheeler, R.; Vrain, E.; Lovett, A.; Collins, A.L.; Jones, J.I.; Johnes, P.; Cleasby, W. An exploration of individual, social and material factors influencing water pollution mitigation behaviours within the farming community. Land Use Policy 2018, 70, 16-26. [CrossRef]

20. Okumah, M.; Ankomah-Hackman, P. Applying conditional process modelling to investigate factors influencing the adoption of water pollution mitigation behaviours. Sustain. Water Resour. Manag. 2020, 6, 17. [CrossRef]

21. Jackson, T. Motivating Sustainable Consumption: A Review of Evidence on Consumer Behaviour and Behavioural Change; Sustainable Development Research Network; University of Surrey: Guildford, UK, 2005.

22. Bamberg, S.; Möser, G. Twenty years after Hines, Hungerford, and Tomera: A new meta-analysis of psycho-social determinants of pro-environmental behaviour. J. Environ. Psychol. 2007, 27, 14-25. [CrossRef]

23. Cheung, M.W.-L.; Hong, R.Y. Applications of meta-analytic structural equation modelling in health psychology: Examples, issues, and recommendations. Heal. Psychol. Rev. 2017, 11, 265-279. [CrossRef]

24. Hovland, C.I.; Janis, I.L.; Kelley, H.H. Communication and Persuasion; Psychological Studies of Opinion Change; Yale University Press: New Haven, CT, USA, 1953. 
25. Petty, R.; Cacioppo, J. Communication and Persuasion: Central and Peripheral Routes to Attitude Change; Springer: New York, NY, USA, 1986.

26. Ajzen, I.; Fishbein, M. Understanding Attitudes and Predicting Social Behaviour; Prentice-Hall Inc.: Englewood Cliffs, NJ, USA, 1980.

27. Ajzen, I. The Theory of Planned Behavior. Organ. Behav. Hum. Decis. Process. 1991, 50, 179-211. [CrossRef]

28. Schwartz, S.H. Awareness of Consequences and the Influence of Moral Norms on Interpersonal Behavior. Sociometry 1968, 31, 355-369. [CrossRef]

29. Schwartz, S.H. Elicitation of moral obligation and self-sacrificing behavior: An experimental study of volunteering to be a bone marrow donor. J. Pers. Soc. Psychol. 1970, 15, 283-293. [CrossRef]

30. Stern, P.C.; Dietz, T.; Abel, T.; Guagnano, G.A.; Kalof, A. A value-belief-norm theory of support for social movements: The case of environmentalism. Hum. Ecol. Rev. 1999, 6, 81-97.

31. Stern, P.C.; Dietz, T. The Value Basis of Environmental Concern. J. Soc. Issues 1994, 50, 65-84. [CrossRef]

32. Stern, P.C. New Environmental Theories: Toward a Coherent Theory of Environmentally Significant Behavior. J. Soc. Issues 2000, 56, 407-424. [CrossRef]

33. Stern, P.C.; Dietz, T.; Black, J.S. Support for environmental protection: The role of moral norms. Popul. Environ. 1985, 8, 204-222. [CrossRef]

34. Boiral, O. Tacit Knowledge and Environmental Management. Long Range Plan. 2002, 35, 291-317. [CrossRef]

35. Bandura, A. Social Learning Theory; Prentice H.: Englewood Cliffs, NJ, USA, 1977.

36. Michie, S.; Johnston, M.; Francis, J.; Hardeman, W.; Eccles, M. From Theory to Intervention: Mapping Theoretically Derived Behavioural Determinants to Behaviour Change Techniques. Appl. Psychol. 2008, 57, 660-680. [CrossRef]

37. Daxini, A.; Ryan, M.; O’Donoghue, C.; Barnes, A.P. Understanding farmers' intentions to follow a nutrient management plan using the theory of planned behaviour. Land Use Policy 2019, 85, 428-437. [CrossRef]

38. Kollmuss, A.; Agyeman, J. Mind the Gap: Why do people act environmentally and what are the barriers to pro-environmental behavior? Environ. Educ. Res. 2002, 8, 239-260. [CrossRef]

39. Steg, L.; Vlek, C. Encouraging pro-environmental behaviour: An integrative review and research agenda. J. Environ. Psychol. 2009, 29, 309-317. [CrossRef]

40. Okumah, M.; Yeboah, A.S.; Amponsah, O. Stakeholders' willingness and motivations to support sustainable water resources management: Insights from a Ghanaian study. Conserv. Sci. Pract. 2020, 2, 170. [CrossRef]

41. Juntti, M.; Potter, C. Interpreting and Reinterpreting Agri-Environmental Policy: Communication, Trust and Knowledge in the Implementation Process. Sociol. Rural. 2002, 42, 216-232. [CrossRef]

42. Schwartz, S.H. Normative influences on altruism. In Advances in Experimental Social Psychology; Academic Press Inc.: New York, NY, USA, 1977; pp. 221-279.

43. Floress, K.; De Jalón, S.G.; Church, S.P.; Babin, N.; Ulrich-Schad, J.D.; Prokopy, L.S. Toward a theory of farmer conservation attitudes: Dual interests and willingness to take action to protect water quality. J. Environ. Psychol. 2017, 53, 73-80. [CrossRef]

44. Gibbons, F.X.; Gerrard, M.; Lane, D.J. A social reaction model of adolescent health risk. In Social Psychological Foundations of Health and Illness; Wiley: Hoboken, NJ, USA, 2003; pp. 107-136.

45. Farrow, K.; Grolleau, G.; Ibanez, L. Social Norms and Pro-environmental Behavior: A Review of the Evidence. Ecol. Econ. 2017, 140, 1-13. [CrossRef]

46. Koricheva, J.; Gurevitch, J. Place of Meta-Analysis Among Other Methods of Research Synthesis, in Handbook of Meta-Analysis in Ecology and Evolution; Koricheva, J., Gurevitch, J., Mengersen, K., Eds.; Princeton University Press: Princeton, NJ, USA; Oxford, UK, 2013.

47. Glass, V.G.; McGraw, B.; Smith, M.L. Meta-Analysis in Social Research; SAGE: London, UK, 1981.

48. Hunter, J.E.; Schmidt, F.L. Fixed Effects vs. Random Effects Meta-Analysis Models: Implications for Cumulative Research Knowledge. Int. J. Sel. Assess. 2000, 8, 275-292. [CrossRef]

49. Hedges, L.V.; Vevea, J.L. Fixed- and Random-Effects Models in Meta-Analysis. Psychol. Methods 1998, 3 , 486-504. [CrossRef]

50. Hedges, L.V.; Olkin, I. Statistical Methods for Meta-Analysis; Academic Press Inc.: New York, NY, USA, 1985.

51. Jennions, M.D. Publication and Related Biases. In Handbook of Meta-analysis in Ecology and Evolution; Koricheva, J., Gurevitch, J., Mengersen, K., Eds.; Princeton University Press: Princeton, NJ, USA; Oxford, UK, 2013. 
52. Hunter, J.E.; Schmidt, F.L. Methods of Meta-Analysis: Correcting Error and Bias in Research Findings, 2nd ed.; Sage: London, UK, 2004.

53. Rosenberg, M.S.; Rothstein, H.R.; Gurevitch, J. Effect Sizes: Conventional Choices and Calculations, in Handbook of Meta-Analysis in Ecology and Evolution; Princeton University Press: Princeton, NJ, USA; Oxford, UK, 2013.

54. Hayes, A.F. Introduction to Mediation, Moderation and Conditional Process Analysis; The Guildford Press: New York, NY, USA; London, UK, 2013.

55. Thompson, S.; Higgins, J.P. How should meta-regression analyses be undertaken and interpreted? Stat. Med. 2002, 21, 1559-1573. [CrossRef]

56. Jak, S.; Cheung, M.W.-L. Testing moderator hypotheses in meta-analytic structural equation modeling using subgroup analysis. Behav. Res. Methods 2018, 50, 1359-1373. [CrossRef] [PubMed]

57. Hooper, D.; Coughlan, J.; Mullen, M.R. Structural Equation Modelling: Guidelines for Determining Model Fit. J. Bus. Res. 2008, 6, 53-60.

58. Hu, L.; Bentler, P.M. Cutoff criteria for fit indexes in covariance structure analysis: Conventional criteria versus new alternatives. Struct. Equ. Model. A Multidiscip. J. 1999, 6, 1-55. [CrossRef]

59. Blackstock, K. Negotiating Change: The importance of Knowledge networks in mitigating diffuse pollution. In Proceedings of the CAIWA 2007, International Conference on Adaptive and Integrated Water Management, Basel, Switzerland, 12-15 September 2007.

60. Morris, J.; Mills, J.; Crawford, I. Promoting farmer uptake of agri-environment schemes: The Countryside Stewardship Arable Options Scheme. Land Use Policy 2000, 17, 241-254. [CrossRef]

61. Phuc, T.X. Why did the forest conservation policy fail in the Vietnamese uplands? Forest conflicts in Ba Vi National Park in Northern Region. Int. J. Environ. Stud. 2009, 66, 59-68. [CrossRef]

62. Hines, J.M.; Hungerford, H.R.; Tomera, A.N. Analysis \& Synthesis of Research on Responsible Environmental Responsible Behavior: A Meta-Analysis. J. Environ. Educ. 1986, 18, 1-8.

63. Kormos, C.E.; Gifford, R. The validity of self-report measures of pro-environmental behavior: A meta-analytic review. J. Environ. Psychol. 2014, 40, 359-371. [CrossRef]

64. Warriner, G.; Mcdougall, G.; Claxton, J. Any data or none at all? Living with inaccuracies in self-reports of residential energy consumption. Environ. Behav. 1984, 503-526. [CrossRef]

65. Huffman, A.H.; Van Der Werff, B.R.; Henning, J.B.; Watrous-Rodriguez, K. When do recycling attitudes predict recycling? An investigation of self-reported versus observed behavior. J. Environ. Psychol. 2014, 38, 262-270. [CrossRef]

66. Han, H.; Hyun, S.S. What influences water conservation and towel reuse practices of hotel guests? Tour. Manag. 2018, 64, 87-97. [CrossRef]

67. Tonglet, M.; Phillips, P.; Read, A.D. Using the Theory of Planned Behaviour to investigate the determinants of recycling behaviour: A case study from Brixworth, UK. Resour. Conserv. Recycl. 2004, 41, 191-214. [CrossRef]

68. Adnan, N.; Nordin, S.M.; Bin Abu Bakar, Z. Understanding and facilitating sustainable agricultural practice: A comprehensive analysis of adoption behaviour among Malaysian paddy farmers. Land Use Policy 2017, 68, 372-382. [CrossRef]

69. Kaiser, F.G.; Scheuthle, H. Two challenges to a moral extension of the theory of planned behavior: Moral norms and just world beliefs in conservationism. Pers. Individ. Differ. 2003, 35, 1033-1048. [CrossRef]

70. Han, H. Travelers' pro-environmental behavior in a green lodging context: Converging value-belief-norm theory and the theory of planned behavior. Tour. Manag. 2015, 47, 164-177. [CrossRef]

71. Raymond, C.M.; Kenter, J.O. Transcendental values and the valuation and management of ecosystem services. Ecosyst. Serv. 2016, 21, 241-257. [CrossRef]

72. Arnocky, S.; Nicol, J.R.; Milfont, T.L. Time Perspective and Sustainable Behavior. Environ. Behav. 2013, 46, 556-582. [CrossRef]

73. Davis, G.; O'Callaghan, F.; Knox, K. Sustainable attitudes and behaviours amongst a sample of non-academic staff. Int. J. Sustain. High. Educ. 2009, 10, 136-151. [CrossRef]

74. Chatzidakis, A.; Kastanakis, M.; Stathopoulou, A. Socio-Cognitive Determinants of Consumers' Support for the Fair Trade Movement. J. Bus. Ethics 2014, 133, 95-109. [CrossRef]

75. Lalani, B.; Dorward, P.; Holloway, G.; Wauters, E. Smallholder farmers' motivations for using Conservation Agriculture and the roles of yield, labour and soil fertility in decision making. Agric. Syst. 2016, 146, 80-90. [CrossRef] 
76. Busse, M.; Menzel, S. The role of perceived socio-spatial distance in adolescents' willingness to engage in pro-environmental behavior. J. Environ. Psychol. 2014, 40, 412-420. [CrossRef]

77. Doran, R.; Larsen, S. The Relative Importance of Social and Personal Norms in Explaining Intentions to Choose Eco-Friendly Travel Options. Int. J. Tour. Res. 2016, 18, 159-166. [CrossRef]

78. Mannetti, L.; Pierro, A.; Livi, S. Recycling: Planned and self-expressive behaviour. J. Environ. Psychol. 2004, 24, 227-236. [CrossRef]

79. Robinson, R.; Smith, C. Psychosocial and demographic variables associated with consumer intention to purchase sustainably produced foods as defined by the Midwest Food Alliance. J. Nutr. Educ. Behav. 2003, 34, 316-325. [CrossRef]

80. Ari, E.; Yilmaz, V. A proposed structural model for housewives' recycling behavior: A case study from Turkey. Ecol. Econ. 2016, 129, 132-142. [CrossRef]

81. Wesselink, R.; Blok, V.; Ringersma, J. Pro-environmental behaviour in the workplace and the role of managers and organisation. J. Clean. Prod. 2017, 168, 1679-1687. [CrossRef]

82. Kim, S.; Jeong, S.-H.; Hwang, Y. Predictors of Pro-Environmental Behaviors of American and Korean Students. Sci. Commun. 2012, 35, 168-188. [CrossRef]

83. Untaru, E.-N.; Ispas, A.; Candrea, A.N.; Luca, M.; Epuran, G. Predictors of individuals' intention to conserve water in a lodging context: The application of an extended Theory of Reasoned Action. Int. J. Hosp. Manag. 2016, 59, 50-59. [CrossRef]

84. Zhang, Y.; Zhang, H.; Zhang, J.; Cheng, S. Predicting residents' pro-environmental behaviors at tourist sites: The role of awareness of disaster's consequences, values, and place attachment. J. Environ. Psychol. 2014, 40, 131-146. [CrossRef]

85. Price, J.; Leviston, Z. Predicting pro-environmental agricultural practices: The social, psychological and contextual influences on land management. J. Rural. Stud. 2014, 34, 65-78. [CrossRef]

86. Ha, H.-Y.; Janda, S. Predicting consumer intentions to purchase energy-efficient products. J. Consum. Mark. 2012, 29, 461-469. [CrossRef]

87. Han, H. The norm activation model and theory-broadening: Individuals' decision-making on environmentallyresponsible convention attendance. J. Environ. Psychol. 2014, 40, 462-471. [CrossRef]

88. Kaiser, F.G. A moral extension of the theory of planned behavior: Norms and anticipated feelings of regret in conservationism. Pers. Individ. Differ. 2006, 41,71-81. [CrossRef]

89. Gärling, T.; Fujii, S.; Gärling, A.; Jakobsson, C. Moderating effects of social value orientation on determinants of proenvironmental behavior intention. J. Environ. Psychol. 2003, 23, 1-9. [CrossRef]

90. Chen, M.-F.; Tung, P.-J. The Moderating Effect of Perceived Lack of Facilities on Consumers' Recycling Intentions. Environ. Behav. 2009, 42, 824-844. [CrossRef]

91. Lin, C.-Y.; Syrgabayeva, D. Mechanism of environmental concern on intention to pay more for renewable energy: Application to a developing country. Asia Pac. Manag. Rev. 2016, 21, 125-134. [CrossRef]

92. Goh, S.K.; Balaji, M. Linking green skepticism to green purchase behavior. J. Clean. Prod. 2016, 131, 629-638. [CrossRef]

93. Xu, X.; Maki, A.; Chen, C.-F.; Dong, B.; Day, J.K. Investigating willingness to save energy and communication about energy use in the American workplace with the attitude-behavior-context model. Energy Res. Soc. Sci. 2017, 32, 13-22. [CrossRef]

94. Poškus, M.S. Investigating pro-Environmental Behaviors of Lithuanian University Students. Curr. Psychol. 2016, 37, 225-233. [CrossRef]

95. Prakash, G.; Pathak, P. Intention to buy eco-friendly packaged products among young consumers of India: A study on developing nation. J. Clean. Prod. 2017, 141, 385-393. [CrossRef]

96. Swaim, J.; Maloni, M.; Napshin, S.A.; Henley, A.B. Influences on Student Intention and Behavior Toward Environmental Sustainability. J. Bus. Ethics 2013, 124, 465-484. [CrossRef]

97. Chen, M.-F. Impact of fear appeals on pro-environmental behavior and crucial determinants. Int. J. Advert. 2015, 35, 74-92. [CrossRef]

98. Duerden, M.D.; Witt, P.A. The impact of direct and indirect experiences on the development of environmental knowledge, attitudes, and behavior. J. Environ. Psychol. 2010, 30, 379-392. [CrossRef]

99. Andow, D.; Filho, M.R.; Carneiro, R.; Lorena, D.; Sujii, E.; Alves, R. Heterogeneity in Intention to Adopt Organic Strawberry Production Practices Among Producers in the Federal District, Brazil. Ecol. Econ. 2017, 140, 177-189. [CrossRef] 
100. Han, H.; Hwang, J.; Kim, J.; Jung, H. Guests' pro-environmental decision-making process: Broadening the norm activation framework in a lodging context. Int. J. Hosp. Manag. 2015, 47, 96-107. [CrossRef]

101. Han, H.; Hyun, S.S. Fostering customers' pro-environmental behavior at a museum. J. Sustain. Tour. 2016, 25, 1240-1256. [CrossRef]

102. Dagher, G.K.; Itani, O.S. Factors influencing green purchasing behaviour: Empirical evidence from the Lebanese consumers. J. Consum. Behav. 2014, 13, 188-195. [CrossRef]

103. Chen, M.-F. Extending the theory of planned behavior model to explain people's energy savings and carbon reduction behavioral intentions to mitigate climate change in Taiwan-moral obligation matters. J. Clean. Prod. 2016, 112, 1746-1753. [CrossRef]

104. Botetzagias, I.; Dima, A.-F.; Malesios, C. Extending the Theory of Planned Behavior in the context of recycling: The role of moral norms and of demographic predictors. Resour. Conserv. Recycl. 2015, 95, 58-67. [CrossRef]

105. Donald, I.; Cooper, S.; Conchie, S. An extended theory of planned behaviour model of the psychological factors affecting commuters' transport mode use. J. Environ. Psychol. 2014, 40, 39-48. [CrossRef]

106. Castaneda, M.G.; Martinez, C.P.; Marte, R.; Roxas, B. Explaining the environmentally-sustainable consumer behavior: A social capital perspective. Soc. Responsib. J. 2015, 11, 658-676. [CrossRef]

107. Van Birgelen, M.; Semeijn, J.; Behrens, P. Explaining pro-environment consumer behavior in air travel. J. Air Transp. Manag. 2011, 17, 125-128. [CrossRef]

108. Abdul-Muhmin, A.G. Explaining consumers? willingness to be environmentally friendly. Int. J. Consum. Stud. 2007, 31, 237-247. [CrossRef]

109. Gonçalves, H.; Viegas, A. Explaining consumer use of renewable energy: Determinants and gender and age moderator effects. J. Glob. Sch. Mark. Sci. 2015, 25, 198-215.

110. Chen, M.-F. An examination of the value-belief-norm theory model in predicting pro-environmental behaviour in Taiwan. Asian J. Soc. Psychol. 2015, 18, 145-151. [CrossRef]

111. Ernst, J.; Blood, N.; Beery, T. Environmental action and student environmental leaders: Exploring the influence of environmental attitudes, locus of control, and sense of personal responsibility. Environ. Educ. Res. 2015, 23, 149-175. [CrossRef]

112. Wynveen, C.; Sutton, S.G. Engaging Great Barrier Reef Stakeholders: Mediation Analyses of Barriers Among the Antecedents of Pro-Environmental Behavior. Hum. Dimens. Wildl. 2016, 22, 126-141. [CrossRef]

113. Blok, V.; Wesselink, R.; Studynka, O.; Kemp, R. Encouraging sustainability in the workplace: A survey on the pro-environmental behaviour of university employees. J. Clean. Prod. 2015, 106, 55-67. [CrossRef]

114. Andersson, L.; Shivarajan, S.; Blau, G. Enacting Ecological Sustainability in the MNC: A Test of an Adapted Value-Belief-Norm Framework. J. Bus. Ethic 2005, 59, 295-305. [CrossRef]

115. Nordlund, A.M.; Garvill, J. Effects of values, problem awareness, and personal norm on willingness to reduce personal car use. J. Environ. Psychol. 2003, 23, 339-347. [CrossRef]

116. Staats, H.; Harland, P.; Wilke, H.A.M. Effecting Durable Change. Environ. Behav. 2016, 36, 341-367. [CrossRef]

117. Andersson, M.; Von Borgstede, C. Differentiation of determinants of low-cost and high-cost recycling. J. Environ. Psychol. 2010, 30, 402-408. [CrossRef]

118. Chen, M.-F.; Tung, P.-J. Developing an extended Theory of Planned Behavior model to predict consumers' intention to visit green hotels. Int. J. Hosp. Manag. 2014, 36, 221-230. [CrossRef]

119. Clark, W.A.; Finley, J.C. Determinants of Water Conservation Intention in Blagoevgrad, Bulgaria. Soc. Nat. Resour. 2007, 20, 613-627. [CrossRef]

120. Prete, M.I.; Piper, L.; Rizzo, C.; Pino, G.; Capestro, M.; Mileti, A.; Pichierri, M.; Amatulli, C.; Peluso, A.M.; Guido, G. Determinants of Southern Italian households' intention to adopt energy efficiency measures in residential buildings. J. Clean. Prod. 2017, 153, 83-91. [CrossRef]

121. Han, H.; Jae, M.; Hwang, J. Cruise travelers' environmentally responsible decision-making: An integrative framework of goal-directed behavior and norm activation process. Int. J. Hosp. Manag. 2016, 53, 94-105. [CrossRef]

122. Klöckner, C.A.; Blöbaum, A. A comprehensive action determination model: Toward a broader understanding of ecological behaviour using the example of travel mode choice. J. Environ. Psychol. 2010, 30, 574-586. [CrossRef]

123. Han, H.; Hwang, J.; Lee, S. Cognitive, affective, normative, and moral triggers of sustainable intentions among convention-goers. J. Environ. Psychol. 2017, 51,1-13. [CrossRef]

124. Lin, J.-C.; Wu, C.-S.; Liu, W.-Y.; Lee, C.-C. Behavioral intentions toward afforestation and carbon reduction by the Taiwanese public. For. Policy Econ. 2012, 14, 119-126. [CrossRef] 
125. Doran, R.; Hanss, D.; Larsen, S. Attitudes, efficacy beliefs, and willingness to pay for environmental protection when travelling. Tour. Hosp. Res. 2015, 15, 281-292. [CrossRef]

126. Deng, J.; Sun, P.; Zhao, F.; Han, X.; Yang, G.; Feng, Y. Analysis of the ecological conservation behavior of farmers in payment for ecosystem service programs in eco-environmentally fragile areas using social psychology models. Sci. Total. Environ. 2016, 550, 382-390. [CrossRef] [PubMed]

127. Knussen, C.; Yule, F.; MacKenzie, J.; Wells, M. An analysis of intentions to recycle household waste: The roles of past behaviour, perceived habit, and perceived lack of facilities. J. Environ. Psychol. 2004, 24, 237-246. [CrossRef]

128. Castro, P.; Garrido, M.; Reis, E.; Menezes, J. Ambivalence and conservation behaviour: An exploratory study on the recycling of metal cans. J. Environ. Psychol. 2009, 29, 24-33. [CrossRef]

129. Bissonnette, M.M.; Contento, I.R. Adolescents' perspectives and food choice behaviors in terms of the environmental impacts of food production practices: Application of a psychosocial model. J. Nutr. Educ. 2001, 33, 72-82. [CrossRef]

130. Meinhold, J.L.; Malkus, A.J. Adolescent Environmental Behaviors. Environ. Behav. 2016, 37, 511-532. [CrossRef]

131. Hunecke, M.; Blöbaum, A.; Matthies, E.; Höger, R. Responsibility and Environment. Environ. Behav. 2001, 33, 830-852. [CrossRef]

132. Guagnano, G.A.; Stern, P.C.; Dietz, T. Influences on Attitude-Behavior Relationships. Environ. Behav. 1995, 27, 699-718. [CrossRef]

133. Cottrell, S.P. Influence of Sociodemographics and Environmental Attitudes on General Responsible Environmental Behavior among Recreational Boaters. Environ. Behav. 2003, 35, 347-375. [CrossRef]

134. Corbett, J.B. Motivations to Participate in Riparian Improvement Programs. Sci. Commun. 2002, 23, $243-263$. [CrossRef]

135. Tanner, C.; Kast, S.W. Promoting sustainable consumption: Determinants of green purchases by Swiss consumers. Psychol. Mark. 2003, 20, 883-902. [CrossRef]

136. Chao, Y.-L.; Lam, S.-P. Measuring Responsible Environmental Behavior: Self-Reported and Other-Reported Measures and Their Differences in Testing a Behavioral Model. Environ. Behav. 2011, 43, 53-71. [CrossRef]

137. Rise, J.; Thompson, M.; Verplanken, B. Measuring implementation intentions in the context of the theory of planned behavior. Scand. J. Psychol. 2003, 44, 87-95. [CrossRef]

138. Laudenslager, M.S.; Holt, D.T. Understanding Air Force Members' Intentions to Participate In Pro-Environmental Behaviors: An Application of the Theory of Planned Behavior. Percept. Mot. Ski. 2004, 98, 1162-1170. [CrossRef]

139. Kaiser, F.G.; Gutscher, H. The Proposition of a General Version of the Theory of Planned Behavior: Predicting Ecological Behavior1. J. Appl. Soc. Psychol. 2003, 33, 586-603. [CrossRef]

140. Hamid, P.N.; Cheng, S.-T. Predicting Antipollution Behavior. Environ. Behav. 1995, 27, 679-698. [CrossRef]

141. Bratt, C. Do Norms and Assumed Consequences Influence Environmental Behavior? Environ. Behav. 1999, 1, 630-656. [CrossRef]

142. Davies, J.; Foxall, G.R.; Pallister, J. Beyond the Intention-Behaviour Mythology. Mark. Theory 2002, 2, $29-113$. [CrossRef]

143. Truelove, H.B.; Joireman, J. Understanding the Relationship Between Christian Orthodoxy and Environmentalism. Environ. Behav. 2009, 41, 806-820. [CrossRef]

144. Joireman, J.A.; Lasane, T.P.; Bennett, J.; Richards, D.; Solaimani, S. Integrating social value orientation and the consideration of future consequences within the extended norm activation model of pro-environmental behaviour. Br. J. Soc. Psychol. 2001, 40, 133-155. [CrossRef] [PubMed]

145. Kaiser, F.G.; Shimoda, T.A. Responsibility as a Predictor of Ecological Behaviour. J. Environ. Psychol. 1999, 19, 243-253. [CrossRef]

146. Kaiser, F.G.; Wölfing, S.; Fuhrer, U. Environmental Attitude and Ecological Behaviour. J. Environ. Psychol. 1999, 19, 1-19. [CrossRef]

147. Minton, A.P.; Rose, R.L. The Effects of Environmental Concern on Environmentally Friendly Consumer Behavior: An Exploratory Study. J. Bus. Res. 1997, 40, 37-48. [CrossRef]

148. Nilsson, M.; Kuller, R. Travel behaviour and environmental concern. Transp. Res. Part D: Transp. Environ. 2000, 5, 211-234. [CrossRef]

149. Tanner, C. Constraints on Environmental Behaviour. J. Environ. Psychol. 1999, 19, 145-157. [CrossRef]

150. Terry, D.J.; Hogg, M.A.; White, K.M. The theory of planned behaviour: Self-identity, social identity and group norms. Br. J. Soc. Psychol. 1999, 38, 225-244. [CrossRef] 
151. Grønhøj, A.; Thøgersen, J. Action speaks louder than words: The effect of personal attitudes and family norms on adolescents' pro-environmental behaviour. J. Econ. Psychol. 2012, 33, 292-302. [CrossRef]

152. Kim, S.-Y.; Yoon, J.; Choi, I. What matters to promote consumers' intention to patronize sustainable business-and-industry (B\&I) food services? Br. Food J. 2016, 118, 2710-2731.

153. Carrico, A.; Riemer, M. Motivating energy conservation in the workplace: An evaluation of the use of group-level feedback and peer education. J. Environ. Psychol. 2011, 31, 1-13. [CrossRef]

154. Liobikienè, G.; Grincevičienè, Š.; Bernatonienė, J. Environmentally friendly behaviour and green purchase in Austria and Lithuania. J. Clean. Prod. 2017, 142, 3789-3797. [CrossRef]

155. Chakraborty, A.; Singh, M.P.; Roy, M.; Filho, W.L.; Sima, M. A study of goal frames shaping pro-environmental behaviour in university students. Int. J. Sustain. High. Educ. 2017, 18, 1291-1310. [CrossRef]

156. Hassan, S.H. The role of Islamic values on green purchase intention. J. Islam. Mark. 2014, 5, 379-395. [CrossRef]

157. Fang, W.-T.; Ng, E.; Chang, M.-C. Physical Outdoor Activity versus Indoor Activity: Their Influence on Environmental Behaviors. Int. J. Environ. Res. Public Heal. 2017, 14, 797. [CrossRef]

158. Choi, A.; Ritchie, B.W.; Fielding, K.S. A Mediation Model of Air Travelers' Voluntary Climate Action. J. Travel Res. 2015, 55, 709-723. [CrossRef]

159. Eriksson, L.; Forward, S.E. Is the intention to travel in a pro-environmental manner and the intention to use the car determined by different factors? Transp. Res. Part D: Transp. Environ. 2011, 16, 372-376. [CrossRef]

160. Forward, S. Exploring people's willingness to bike using a combination of the theory of planned behavioural and the transtheoretical model. Eur. Rev. Appl. Psychol. 2014, 64, 151-159. [CrossRef]

161. Mobley, C.; Vagias, W.M.; DeWard, S.L. Exploring Additional Determinants of Environmentally Responsible Behavior: The Influence of Environmental Literature and Environmental Attitudes. Environ. Behav. 2009, 42, 420-447. [CrossRef]

162. Echegaray, F.; Hansstein, F. Assessing the intention-behavior gap in electronic waste recycling: The case of Brazil. J. Clean. Prod. 2017, 142, 180-190. [CrossRef]

163. Eriksson, L.; Garvill, J.; Nordlund, A.M. Acceptability of travel demand management measures: The importance of problem awareness, personal norm, freedom, and fairness. J. Environ. Psychol. 2006, 26, 15-26. [CrossRef]

164. Allen, J.B.; Ferrand, J.L. Environmental Locus of Control, Sympathy, And Pro-environmental Behavior: A Test of Geller's Actively Caring Hypothesis. Environ. Behav. 1999, 31, 338-353. [CrossRef]

165. Gregory, G.D.; di Leo, M. Repeated behaviour and environmental psychology: The role of personal involvement and habit formation in explaining water consumption. J. Appl. Soc. Psychol. 2003, 33, 1261-1296. [CrossRef]

166. Lynne, G.D.; Casey, C.F.; Hodges, A.; Rahmani, M. Conservation technology adoption decisions and the theory of planned behavior. J. Econ. Psychol. 1995, 16, 581-598. [CrossRef]

167. Werner, C.M.; Mäkelä, E. Motivations and Behaviors that Support Recycling. J. Environ. Psychol. 1998, 18, 373-386. [CrossRef]

168. Jorgen, G.; Agneta, M.; Annika, N. Effects of increased awareness on choice of travel mode. Transportation 2003, 30, 63-79.

169. Bamberg, S.; Hunecke, M.; Blöbaum, A. Social context, personal norms and the use of public transportation: Two field studies. J. Environ. Psychol. 2007, 27, 190-203. [CrossRef]

170. Veludo-De-Oliveira, T.; Pallister, J.G.; Foxall, G.R. Accounting for Sustained Volunteering by Young People: An Expanded TPB. Volunt. Int. J. Volunt. Nonprofit Organ. 2012, 24, 1180-1198. [CrossRef]

171. Thøgersen, J.; Ölander, F. The Dynamic Interaction of Personal Norms and Environment-Friendly Buying Behavior: A Panel Study 1. J. Appl. Soc. Psychol. 2006, 36, 1758-1780.

(C) 2020 by the authors. Licensee MDPI, Basel, Switzerland. This article is an open access article distributed under the terms and conditions of the Creative Commons Attribution (CC BY) license (http://creativecommons.org/licenses/by/4.0/). 